\title{
Exceptionally large block-and-ash flows: a detailed study of the 2005 and 2010 eruption deposits of Shiveluch volcano
}

5

${ }^{1}$ Department of Physical Sciences, Concord University, 1000 Vermillion St. Athens, West Virginia, USA

${ }^{2}$ Institute of Volcanology and Seismology, Russia

${ }^{3}$ Department of Geology and Environmental Science, University of Pittsburgh USA

\section{PREPRINT: THIS PAPER HAS NOT YET UNDERGONE THE PEER-REVIEW PROCES}

\section{ABSTRACT}

Two of the largest known historic block-and-ash flow (BAF) fields are located on Shiveluch volcano, Kamchatka. The deposits were produced during retrogressive and pulsatory dome collapse events that occurred over 6-9 hour-long eruptions on 27-28 February 2005 and 27 October 2010. The BAFs that were produced by these partial dome collapse events extend up to $19 \mathrm{~km}$

15 from the dome and inundate areas of 24.1 and $22.3 \mathrm{~km}^{2}$. We used satellite and field data to investigate the surface morphology of the BAF deposits and their impact on the surrounding area. The deposit surfaces contain overlapping lobate deposits, compaction ridges, levees and channel morphologies, degassing structures, abundant large dome blocks, and large areas of syn- or immediately-post-depositional remobilization, as shown by bench scallops and arcuate scarps. The dome-collapse events produced flows with two components: the dense block-and-ash component of the flows, and the associated dilute pyroclastic surges. The surge components traveled beyond the main flow and killed vegetation to distances of nearly $300 \mathrm{~m}$. The 2005 dome collapse event produced a BAF that extended $17.8 \mathrm{~km}$ from the dome and emplaced a large fan deposit and associated surge, which destroyed an area of forest $10 \mathrm{~km}^{2}$ in size. The October 2010 event also produced a large fan deposit with a distal channelized deposit that extended an additional $5.4 \mathrm{~km}$ beyond the main 2010 fan for a total distance from the dome of $19 \mathrm{~km}$. Since deposition, fluvial erosion and deposition produced large areas comprised of dendritic and braided channel deposits. The surface morphology of the deposits as revealed in satellite imagery and observed in stratigraphic sections give insight into the pulsatory nature of the dome collapse events, the final moments of deposition, and the subsequent erosion of the deposits. Preservation of the deposits is exceptional due to the high-latitude location, where snow-cover is present for much of the year and erosion is limited. This detailed study of the Shiveluch deposits provides rare insight into the processes responsible for generation of large and long run-out dome-collapse BAFs in both channelized and non-channelized environments.

\section{INTRODUCTION}

BAFs are a result of the partial collapse of a lava dome and can be triggered by volcanic and non-volcanic processes, such as eruptions, earthquakes, or rainfall, which can make them difficult to forecast [Carn et al., 2004]. However, with the 
issue probabilistic forecasts of dome-collapse and related pyroclastic flows [Wright et al., 2017]. Experiments and numerical simulations of granular flows are increasingly used in combination with geological information to understand the runout extent and distribution of hazards associated with volcanic eruptions [e.g. Charbonnier and Gertisser, 2009; Oramas-Dorta et al., 2012]. Shiveluch, the northernmost and one of the most active volcanoes in Kamchatka, Russia, produces some of the largest

5 dome-collapse-driven block-and-ash (BAF) deposits in historical times. Recent activity resumed in 1980 and after a period of quiescence the current dome-growth episode began in 2001. Activity involves frequent gravitational failure of hot dome rock, which results in a wide range in deposit types from small rockfalls that do not extend beyond the dome to major partial dome failure events with volumes as large as $0.28 \mathrm{~km}^{3}$ [Ivanov 1980; Dvigalo, V.N., 1988; Dvigalo et al., 2011; Shevchenko and Svirid, 2014]. Eight large BAFs were produced on 19 May 2001, 10 May 2004, 27-28 February 2005, 18-19 December 2007,

10 25-26 June 2009, 28 October 2010, 26 July 2013, and 3 December 2013 [Fedotov et al., 2001; Fedotov et al., 2004; Dirksen et al., 2006; Girina et al., 2004; Gorbch 2006; Girina et al., 2006; Girina et al., 2007; Carter and Ramsey, 2010; Ovsyannikov and Manevich, 2010; Gorbach et al., 2013; Zharinov and Demyanchuk, 2013; Girina and Nuzhdaev, 2014; Shevchenko et al., 2015; Ramsey, 2016; Krippner et al., 2018]. The two largest deposits were emplaced during the February 2005 and October 2010 events (Figure 1) and are investigated using field and satellite data. The satellite data include the Advanced Spaceborne

15 Thermal Emission and Reflection Radiometer (ASTER) Visible-Near Infrared (VNIR), and high-resolution WorldView-02 and QuickBird-02 sensor datasets.

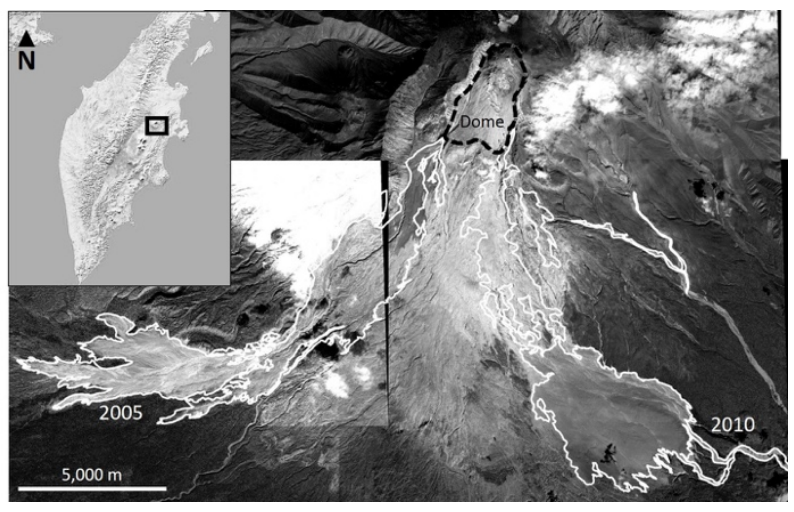

Figure 1. The Shiveluch 2005 and 2010 BAF deposits originating from partial dome collapse. The BAF deposit boundaries are shown by the white lines, and the dome perimeter is annotated with the black dashed line. The left image is a WorldView-02 scene (panchromatic band) acquired on 29 September 2010. The right image is a QuickBird-02 scene (panchromatic band) acquired on 27 August 2013. The location is given in the insert box, modified ESRI Basemap Copyright: (C) 2014 National Geographic Society, icubed.

The hornblende-plagioclase andesite lava dome at Shiveluch [Gorbach et al., 2016] has temperatures that range over of hundreds of degrees, from a cooler outer carapace to the hotter interior [Krippner et al., 2018]. The inner and hotter dome material is likely degassed to a lesser extent, resulting in pore-pressure-induced autobrecciation, in addition to the mechanical breakage from clast interactions during gravitational failure and the flowage processes that followed. The role of explosive and mechanical-based fragmentation is been discussed in work by Dellino and La Volpe [1995], Bursik et al. [2005], and Mackaman-Lofland et al. [2014]. These workers document a range of transitional facies between debris avalanches and vesicular pyroclastic flows with BAFs somewhere in between. Perhaps, the mix of gravitational failure with hot, explosive 
fragmentation leads to BAF deposits that share some similarities with both debris avalanches and column-collapse pyroclastic flows. This information allows us to describe the depositional processes that are responsible for the distribution of these extreme end-members of dome-collapse related pyroclastic density currents (PDCs).

\section{Methodology}

The 2005 and 2010 BAF deposits were examined in detail using panchromatic high-resolution satellite data (Table 1). The deposit surfaces were characterized based on visual surface morphological features, relative roughness, and block content using the Esri ArcMap program. The relative roughness is visible in the panchromatic images as variations in the tone due to the reflection of light. Smoother areas have less color variation than areas with higher roughness. Surface blocks larger than

10 the pixel size indicated in Table 1 are visible in the panchromatic data as bright pixels where the smooth block reflects more light, and a contrasting dark shadow behind the block. Areas of interest were identified using these features and later investigated further in the field together with stratigraphic profiles were analysed where available. Aerial images were collected using a drone in the summer of 2016.

15 Table 1. Parameters for the high-resolution satellite datasets used in this study.

\begin{tabular}{llccc}
\hline Satellite sensor & $\begin{array}{c}\text { Acquisition } \\
\text { Date }\end{array}$ & $\begin{array}{c}\text { Spectral Range } \\
\mathbf{( n m )} \\
\text { WorldView-02 }\end{array}$ & $\begin{array}{c}\text { Spatial Resolution } \\
\text { /swath width (at } \\
\text { nadir) }\end{array}$ & Deposit imaged \\
\hline QuickBird-02 & 27-Aur-05 & $\begin{array}{c}\text { Panchromatic } \\
450-800\end{array}$ & $0.46 \mathrm{~m} / 16.4 \mathrm{~km}$ & Shiveluch 2005 BAF \\
\hline
\end{tabular}

\section{RESULTS}

\section{Surface morphology of BAF deposits}

The 2005 and 2010 deposits share commonalities in surface morphology because of the similar source/dome material,

20 eruption style, flow transportation, and depositional processes. We have assigned nine surface morphology classes across the two deposits that share similar physical characteristics (Figure 2). 


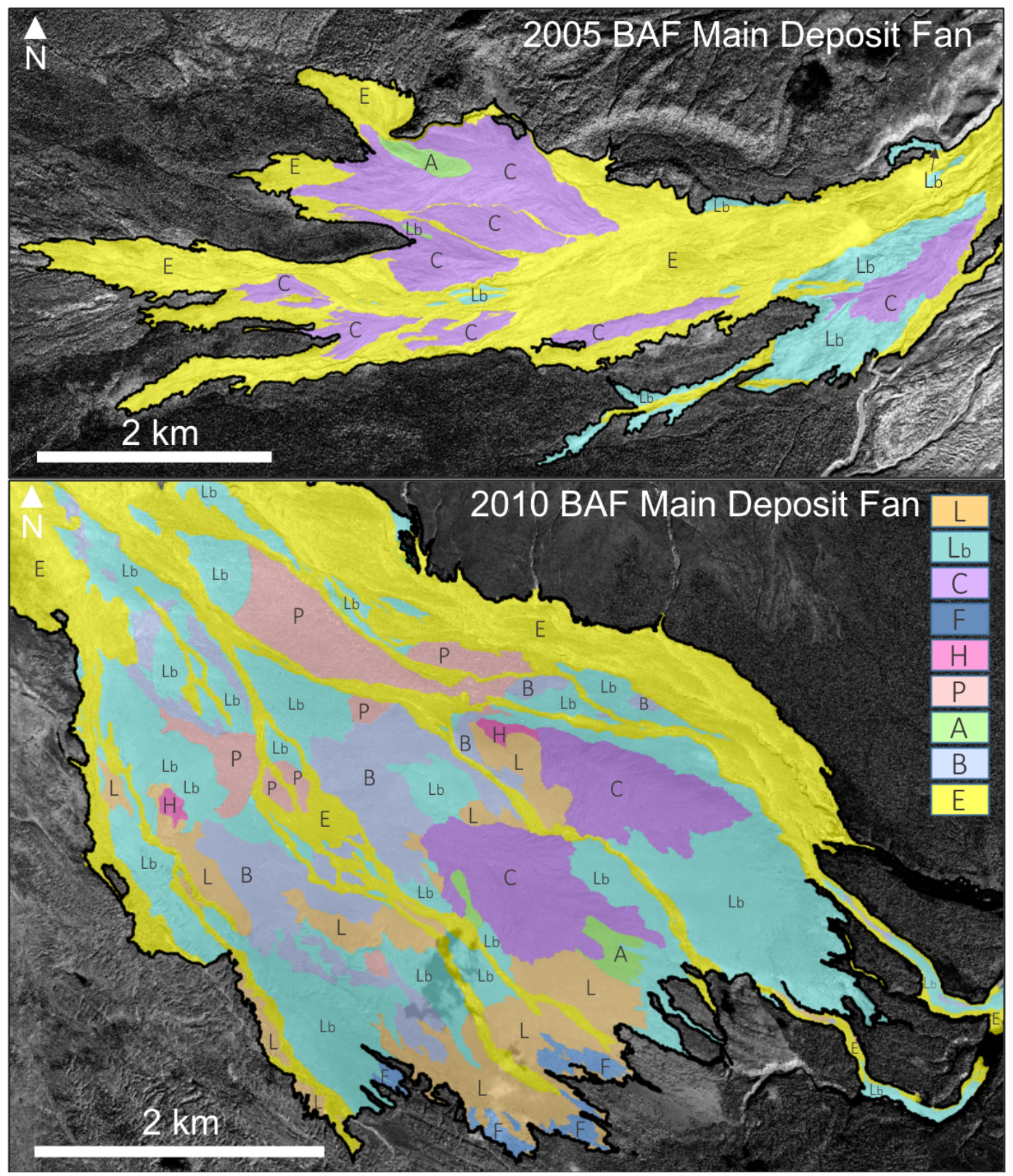

Figure 2. The nine BAF deposit surface morphology classes that represent characteristics across the 2005 and 2010 main deposit fans and channelized deposits. The colors and letters correlate to the descriptions on the next page and are applied to both the 2005 (top) and 2010 (bottom) images. 


\begin{tabular}{|c|c|c|c|}
\hline & Classes & Description & Example \\
\hline $\mathrm{L}$ & $\begin{array}{l}\text { Low-relief with rare to } \\
\text { absent surface blocks }\end{array}$ & $\begin{array}{l}\text { Contain rare large surface blocks and low } \\
\text { surface relief with no features casting } \\
\text { shadows onto the deposit surface. Faint } \\
\text { lobe terminations in places. }\end{array}$ & \\
\hline $\mathrm{Lb}$ & $\begin{array}{l}\text { Low-relief with surface } \\
\text { blocks }\end{array}$ & $\begin{array}{l}\text { Surface blocks common. Low surface } \\
\text { relief with no features casting shadows } \\
\text { onto the deposit surface. Faint lobe } \\
\text { terminations visible in places. }\end{array}$ & \\
\hline C & Composite Lobes & $\begin{array}{l}\text { Series of overlapping lobes with varying } \\
\text { sizes, extents, and shapes. Levees and } \\
\text { channels may be present. Lobes have } \\
\text { ridge and furrow morphology. Surface } \\
\text { blocks are variable. }\end{array}$ & \\
\hline $\mathrm{F}$ & Feathery terminations & $\begin{array}{l}\text { Occur at the distal end of the main } \\
\text { deposit fan. They are block-poor with } \\
\text { low-relief, and contain bands of low- } \\
\text { density entrained material around the } \\
\text { boundaries. }\end{array}$ & \\
\hline $\mathrm{H}$ & Herringbone & $\begin{array}{l}\text { Sequence of repeating v-shaped features } \\
\text { or ridges, with the vertexes pointing } \\
\text { upstream. }\end{array}$ & \\
\hline $\mathrm{P}$ & Parallel linear scarps & $\begin{array}{l}\text { Repeating, near-parallel curvilinear } \\
\text { scarps. Block contents are variable. }\end{array}$ & \\
\hline A & Arcuate scarp & $\begin{array}{l}\text { Singular or repeating scarps. Irregular } \\
\text { remobilized deposit surfaces within and } \\
\text { downstream of the scarp. Terminations } \\
\text { are commonly lobate or rounded. }\end{array}$ & \\
\hline B & $\begin{array}{l}\text { Curvilinear bench and } \\
\text { scarp }\end{array}$ & $\begin{array}{l}\text { Multiple arcuate scarps, commonly } \\
\text { joined or in subsequent steps. Areas } \\
\text { below the scarps are irregular and } \\
\text { sometimes contain lobate features within } \\
\text { the remobilized material. }\end{array}$ & \\
\hline $\mathrm{E}$ & Surface erosion & $\begin{array}{l}\text { Fluvial sheet-erosion or meandering and } \\
\text { braided erosion channels. Surface block } \\
\text { contents are variable, and are higher } \\
\text { within channels. }\end{array}$ & $50 \mathrm{~m}$ \\
\hline
\end{tabular}

Figure 2 continued. 


\subsection{The Shiveluch 27-28 February 2005 BAF deposit}

The BAF deposit has two main facies: 1) the fan deposit, and 2) the BAF-related pyroclastic surge deposit that surrounds the fan (Figures 3 and 4). The 2005 BAF deposit is over $20 \mathrm{~m}$ thick in places and is composed of poorly sorted ash and lapilli matrix with abundant sub-angular to sub-rounded blocks that are up to $6 \mathrm{~m}$ in diameter. The clasts are composed of

5 fragmented dome material as well as accidental pumiceous and lithic clasts picked up by the flows from the substrate during propagation. By the time of fieldwork in 2015, several sections were cut through this deposit by fluvial erosion exposing the internal stratigraphy down to the depth of $20 \mathrm{~m}$.

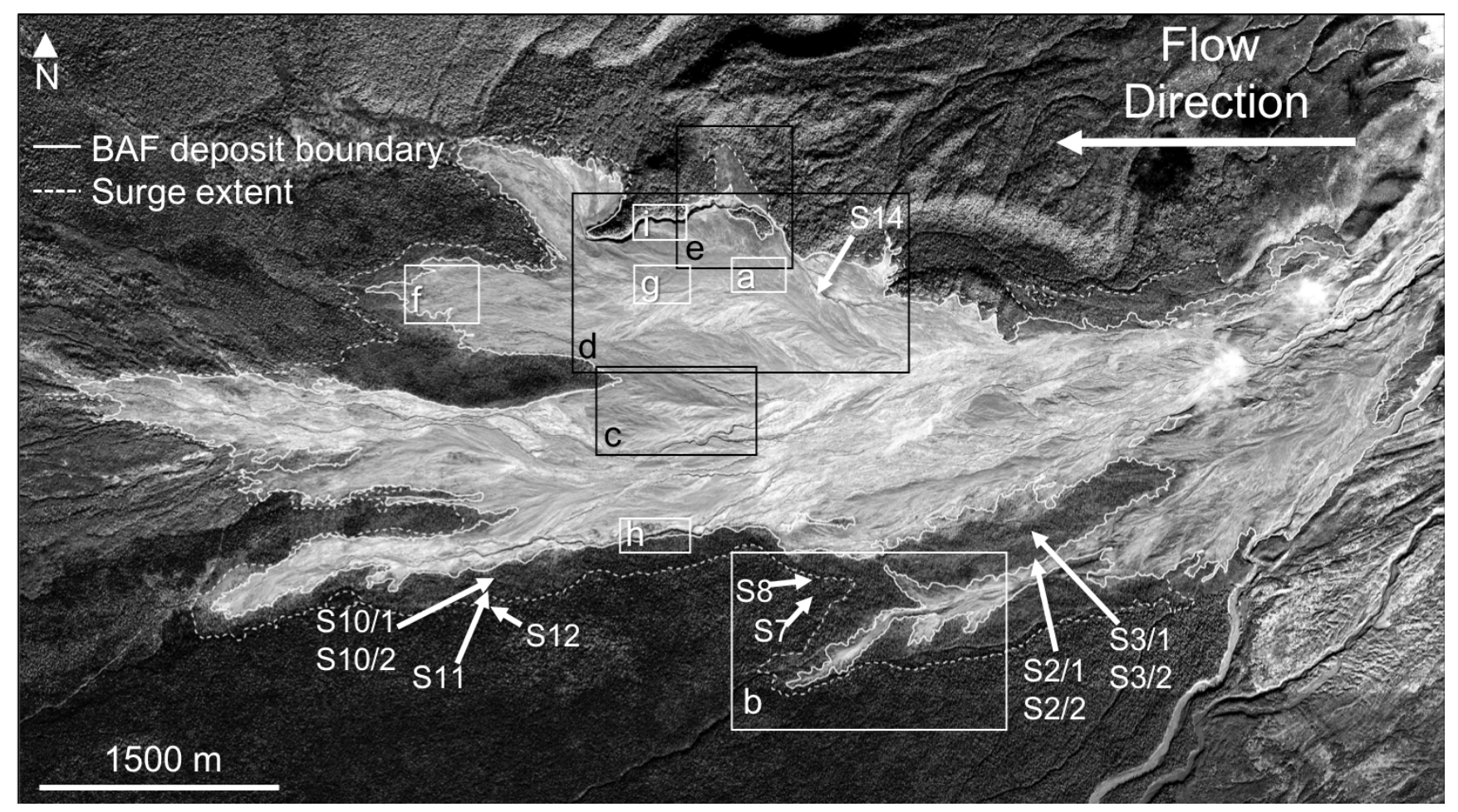

Figure 3. The Shiveluch 2005 BAF main deposit fan area (panchromatic WorldView-02 scene acquired on 29 September 2010 ). The 10 white boxes and letters indicate the locations of photographs shown in the following section. The black boxes and letters indicate the enlargements of this WorldView-02 scene in subsequent figures. a) Figure 5; b) Figure 6; c) Figure 7; d) Figure 8; e) Figure 9; f) Figure 10; g) Figure 11; h) Figure 14; i) Figure 15. The locations of the February 2005 pyroclastic surge deposit sample sites are labelled (S1, etc.) for the descriptions and componentry analyses that are given in Figure 4 . 


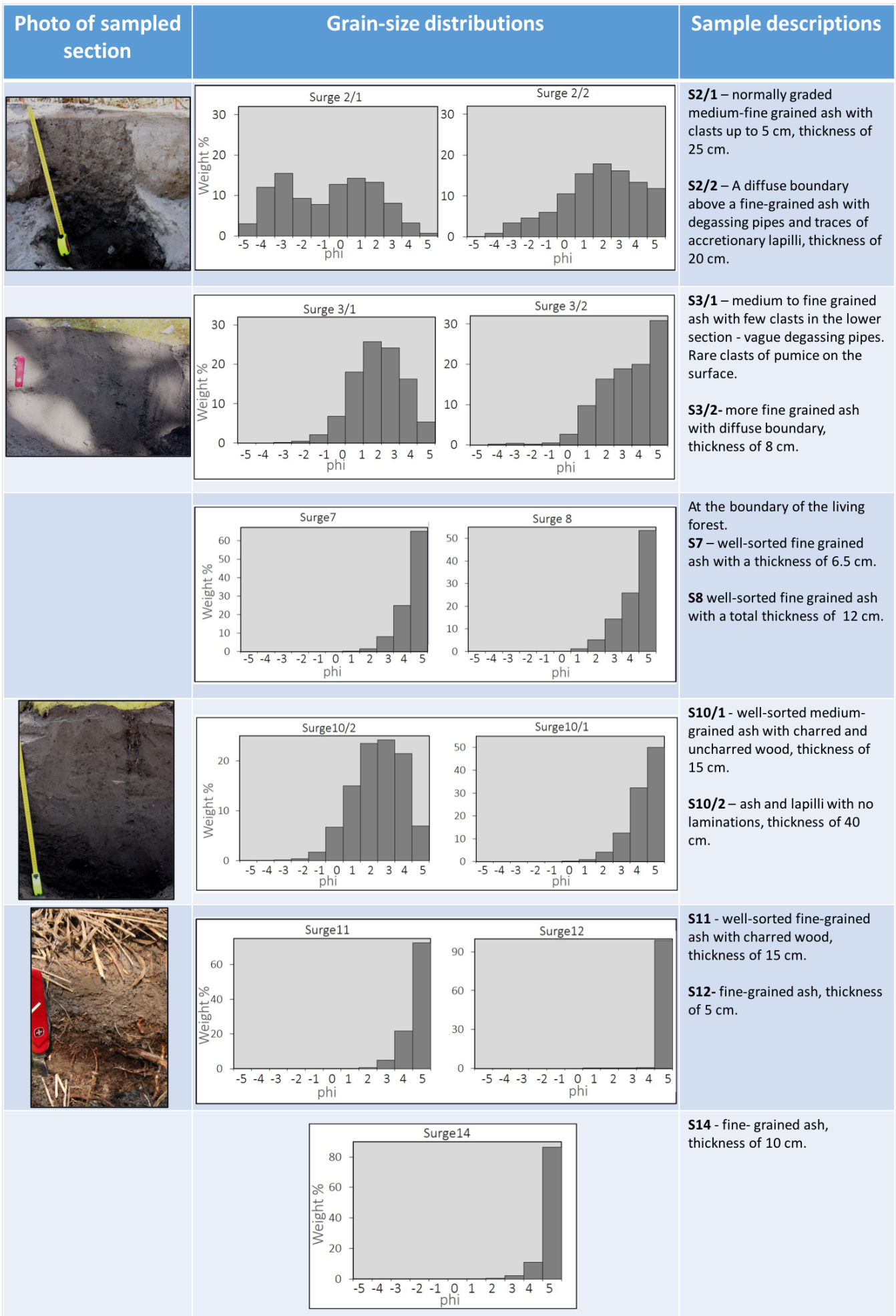


Figure 4. The pyroclastic surge deposit sections described in this study, with grain-size distributions in relative abundances (measured in the phi size scale) and the corresponding sample site. Locations of the pyroclastic surge sections are shown in Figure 3.

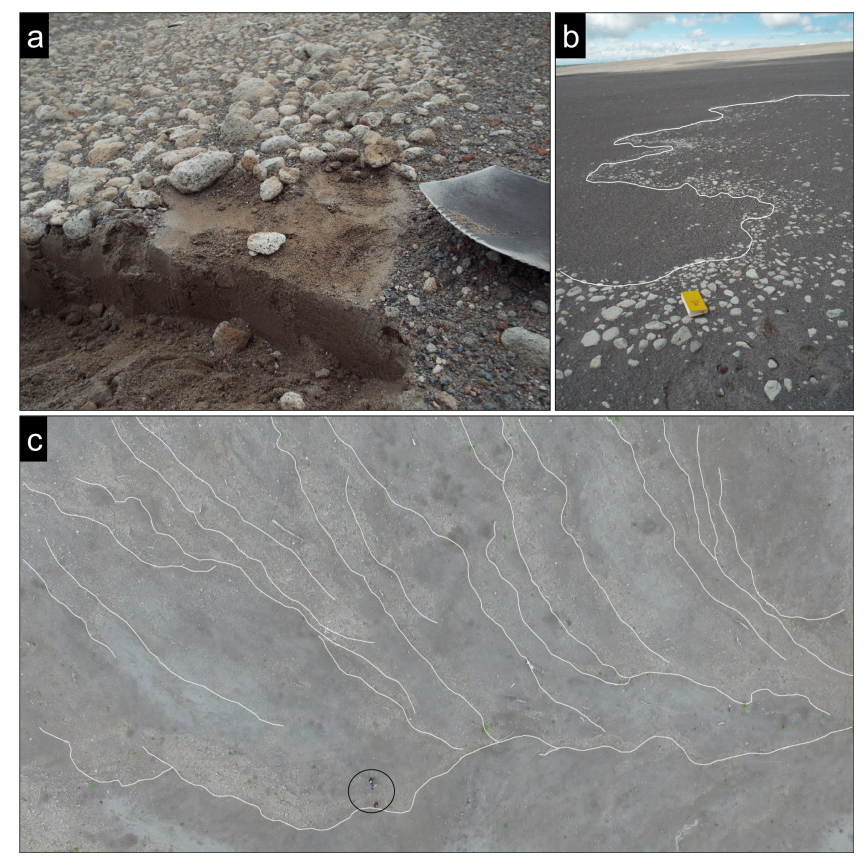

5 Figure 5. a) lighter-colored lineaments of lower-density andesite clasts situated on the surface of the 2005 BAF deposit; b) the lowdensity bands were deposited along the flow fronts of BAF pulses (the yellow field notebook is 12 x $19 \mathrm{~cm}$ for scale); c) drone photograph looking down on to the BAF deposit surface where multiple flow pulse fronts are lined with the low-density clasts. The location of these images is given in Figure 3, box a.

The 2005 BAF deposit is divided into several areas based on the deposit thickness, surface morphology, and distance

10 from the dome. The proximal deposit area extends S-SW from the dome for $9.5 \mathrm{~km}$ along the western boundary of the 1964 debris avalanche deposit and the 1964 pumiceous pyroclastic flow deposit. The proximal area comprises an upper fan section covering $\sim 9.2 \mathrm{~km}^{2}$ with a length of $5 \mathrm{~km}$ and maximum width of $\sim 2.3 \mathrm{~km}$. It does not appear to be as thick as the distal area emplaced on a shallower slope angle. South of the upper fan, the deposit is concentrated in the Baidarnaya River channel for $\sim 2 \mathrm{~km}$, after which it extends westward into a main deposit fan, including a smaller $1.9 \mathrm{~km}^{2}$ section emplaced slightly to the

15 south where the BAF traveled over the channel wall [Krippner et al., 2018]. Geometric parameters of the deposit are summarized in Table 2. 
Table 2. Geometric parameters of the 2005 and 2010 BAF deposits. Deposit and collapse scar values are from Krippner et al., 2018. 1Zharinov and Demyanchuk, 2013, ${ }^{2}$ Zharinov and Demyanchuk, 2008, ${ }^{3}$ Shevchenko et al., 2015, ${ }^{4}$ Shevchenko and Svirid, 2014, 5Dvigalo et al., 2011.

\begin{tabular}{lll}
\hline & $\mathbf{2 7 - 2 8}$ February 2005 & 28 October 2010 \\
\hline Collapse scar area $\left(\mathrm{km}^{2}\right)$ & 0.86 & 1.17 \\
Collapse scar max. width x length $(\mathrm{m})$ & $550 \times 2400$ & $1100 \times 2540$ \\
BAF runout distance $(\mathrm{km})$ & $15.6-17.8$ & $16.4-19$ \\
BAF runout from dome base $(\mathrm{km})$ & 15.4 & 15.7 \\
BAF deposit area $\left(\mathrm{km}^{2}\right)$ & 24.1 & 22.3 \\
Maximum deposit width $(\mathrm{m})$ & 2490 & 4100 \\
Flow direction & $\mathrm{SW}, \mathrm{W}$ & $\mathrm{S}, \mathrm{SE}$ \\
Channelized deposit length $(\mathrm{m})$ & 2000 & 5400 \\
Main deposition begins $(\mathrm{m}$ from dome base) & 9500 & 7300 \\
Levee/channel & $\mathrm{Yes}$ & $\mathrm{Yes}$ \\
Relative dome height $(\mathrm{m})$ & $517^{1}$ & $563^{1}$ \\
Dome volume prior to collapse $\left(\mathrm{km}^{3}\right)$ & $>0.47^{2}$ & $0.54^{3}$ \\
Dome collapse volume $\left(\mathrm{km}^{3}\right)$ & $0.11^{4}$ & $0.28^{5}$ \\
\hline
\end{tabular}

The distal area comprises the bulk of the material in the main deposit fan where material is emplaced beyond the 1964 debris avalanche fan. The BAF destroyed $10 \mathrm{~km}^{2}$ of forest and buried the pre-existing Baidarnaya River channel. The main deposit fan terminates in five lobes, each surrounded by a fringe of singed trees that are clearly visible in satellite data and aerial photographs (Figure 6). Friable clastic material stranded on top of blocks protrude over $3 \mathrm{~m}$ above the surface and impact marks on standing trees indicate that the BAF was inflated to at least $3 \mathrm{~m}$ thicker than the resulting deposit.
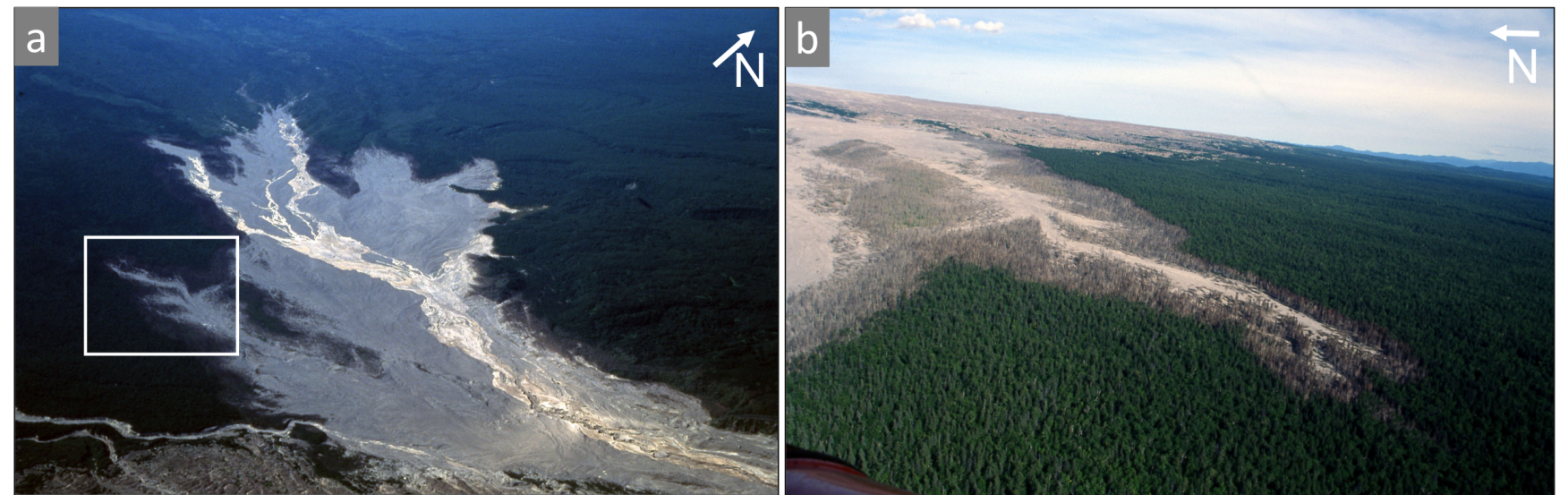

Figure 6. a) An aerial photographs showing the 2005 main BAF deposit fan. a) View of the fan in September 2005; the lighter linear areas on the deposit surface are post-depositional erosion channels. The white box indicates the lobe shown in (b); b) Detailed view of the flow lobe of the fan showing a zone of singed trees (mostly larch and stone birch) up to several hundred meters wide. The trees were damaged by low-energy, hot, and fine-grained pyroclastic surge that accompanied the BAF emplacement. The photograph was taken in August 2012 from the SW. The location of b is given in Figure 3, box b. Photos by A. Belousov.

Areas of undisturbed deposit surface contain long and narrow (to $\sim 180 \mathrm{~m}$ wide and exceeding 2,000 $\mathrm{m}$ long) sinuous channelized features that form a ridge and furrow morphology (Figure 7). Linear levees are infrequently present on the surface. 
Other areas are comparatively smooth with more diffuse boundaries. The channels and lobes radially spread out from a central channel in a dendritic-like pattern. The thickest deposit area is the northern section of the main fan, which is composed of a series of overlapping lobes with varying size, extent, and shape, that become shorter towards the central apex. These features comprise the composite lobate class (Figure 8). The composite lobate features contain numerous flow fronts visible throughout

5 the deposit fan area due to the lighter-colored entrained clasts. The easternmost/upstream end of the composite lobate feature contains two visible 'feeder channels' with the uppermost channel slightly offset from the underlying channel (Figure 8).

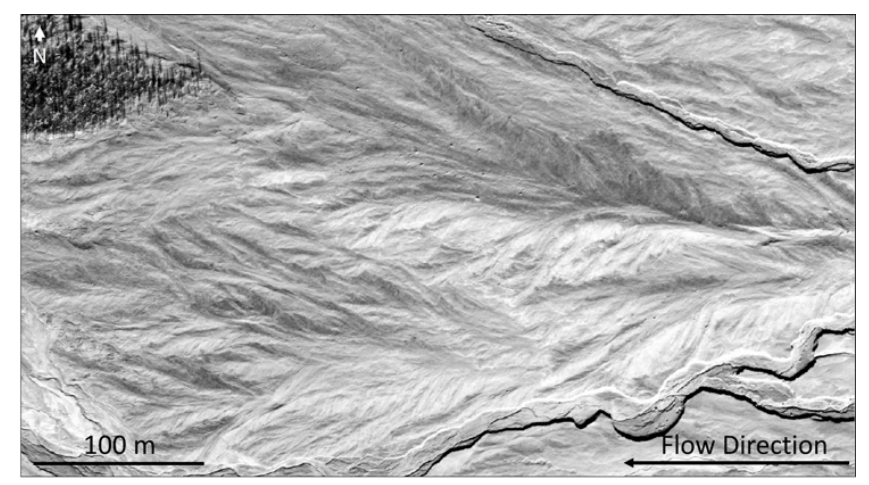

Figure 7. The sinuous lobate 2005 BAF deposit surface. The darker area in the top-left corner is forest that was killed by the associated pyroclastic surge. The BAF flow direction is indicated by the arrow. Panchromatic WorldView-02 image acquired on 29 10 September 2010; the location of this area is indicated in Figure 6, box c. 


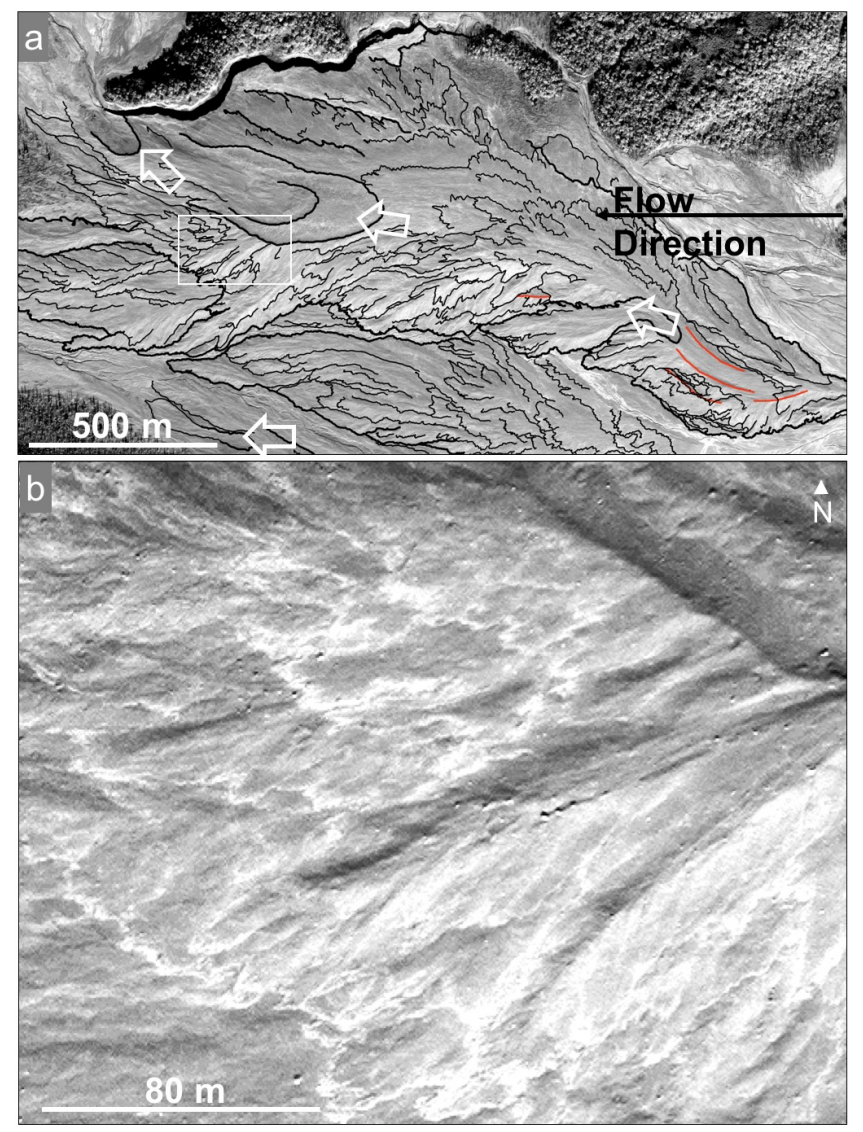

Figure 8. An area of the 2005 BAF deposit displaying the composite lobate class. The distal edges of singular pulses of BAF material are indicated by bands of low-density material deposited at the flow front and are visible as brighter lineations. a) Thin black lines annotate the flow front lineations and the thick black lines are significant flow boundaries. The red lines indicate the channels and 5 the white arrows indicate areas of remobilization (the arcuate scarp morphology). White box indicates the area shown in (b); b) Enlarged area showing the white lineations in the QuickBird-02 scene acquired on 27 August 2010. The location of (a) is indicated in Figure 3, box d.

\subsubsection{Vegetation damage resulting from the $2005 B A F$}

Forest die off and colonization of plants on the hot BAF deposits were been previously examined by Grishin [2009;

10 2012]. Four zones of vegetation damage are present in and around the 2005 BAF main deposit fan (Figure 9): 1) complete tree removal or burial; 2) tree stumps remaining with the rest of the tree removed and felled trees are lying on the deposit surface; 3) trees with foliage removed but remain standing; and 4) no tree damage beyond a sharp transition boundary. Trees that were overcome by the BAF were either buried or removed and transported to the distal edges of the deposit. These deposited singularly or as tree dams where snags accumulated in piles with blocks suspended $>2-3 \mathrm{~m}$ above the current surface of the

15 flow (Figure 10). Logs and tree limbs are also observed in deposits that are piled against and wrapped around standing trees. Many of the standing and felled trees are stripped of their limbs whereas others still have branches attached. In addition, many of the trees have segments where branches were removed down to the bark collar, are frayed and sometimes charred. The surfaces contain impact marks and varying degrees of bark damage or complete removal. Some impact marks contain charring. 
The degree of charring varies from completely charred (relatively rare) with portions of the wood burned away and sometimes leaving a hollow trunk; charred at the base of snag in contact with the deposit; and stumps that lie on the deposit with smooth, charred bases that are possibly as a result of burning while upright in the hot deposit, causing the tree to topple. The highest degree of charring is found along the distal edge of the BAF (Figure 10a). The perimeter around the main body of the flow

5 where the trees were singed but left standing. This indicates the distal extent of the detached pyroclastic surge. Some of the singed trees survived, suggesting that the surge was short-lived and not in contact with the trees long enough to cause carbonization. In 2015, it was noted that vegetation is beginning to re-grow in this area.

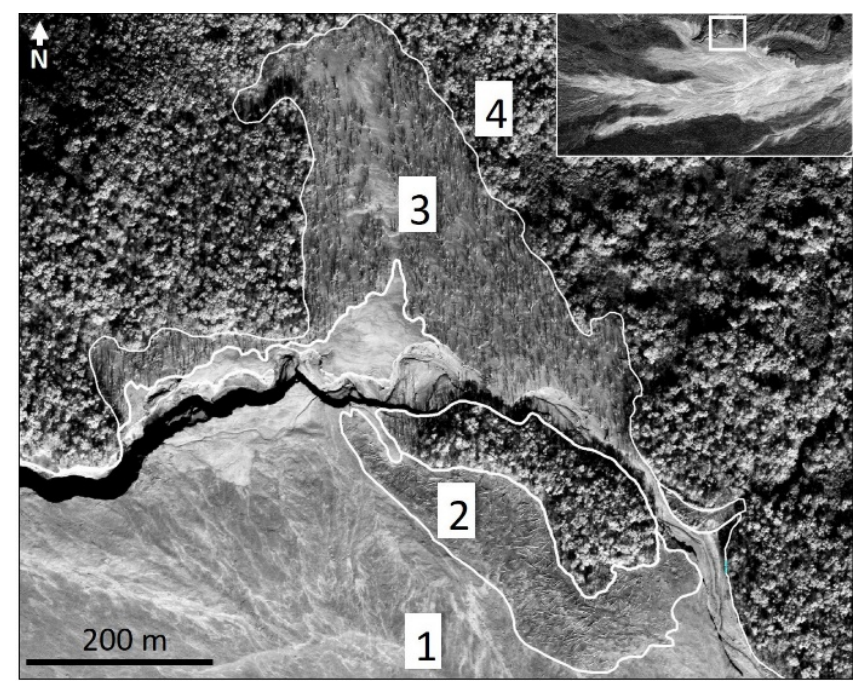

Figure 9. Four zones of vegetation damage: 1) complete tree removal and/or complete burial by deposit; 2) tree stumps 10 remaining/felled trees in situ; 3 ) singe zone where dead trees remain standing out to $280 \mathrm{~m}$ from the BAF deposit; 4) No tree damage. The location of this area is given in Figure 3, box e. 


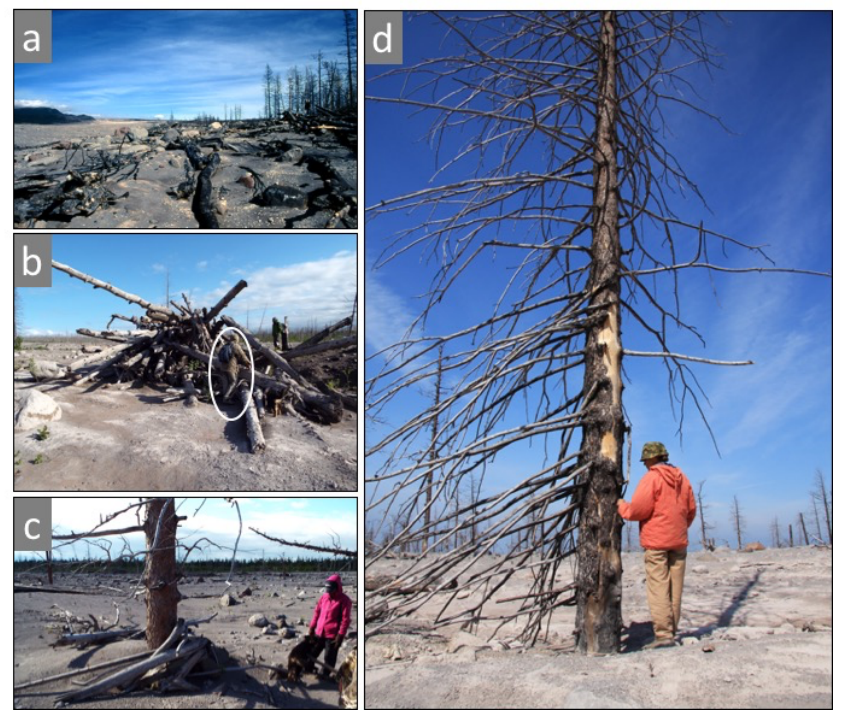

Figure 10. a) knocked down and partly burned trees along the lateral edge of the 2005 deposit. Some of the trees withstood the dynamic action of the block-and-ash flow, but fell down some time later when the bases of their trunks were charred on the contact with the deposit; b) a tree dam at the distal edge of the 2005 main deposit fan, man in circle for scale; c) trees broken and wrapped 5 around a standing tree; d) Bark and branches removed on the stoss side of the tree up to the height of $3.5 \mathrm{~m}$ above the surface of the 2005 deposit. The elevation of the damaged tree trunk indicates the thickness of the gas-inflated BAF before its final deposition. The location of these photos is given in Figure 3, box $\mathrm{f}$.

\subsubsection{Deposit remobilization}

The surface of the thickest area of the 2005 BAF deposit contains a series of four arcuate scarps covering an area of

$10 \quad 0.11 \mathrm{~km}^{2}$ (Figure 8). The scarps are 3-4 $\mathrm{m}$ high and open towards the west. Small parallel ridges that are aligned perpendicular to the flow direction are visible on the surface within the arcuate scarps. These ridges are visible both in the field and in the satellite data. They are interpreted to be headwall scarps and this area is remobilized material with compression ridges. The three uppermost scarps are nested, indicating that they originated through a series of closely-spaced remobilization events that occurring soon (minutes?) after the primary deposition. The fourth arcuate scarp is near the flow terminus and opens to the

15 northwest onto an open plain.

\subsubsection{Degassing Structures}

Some of the thickest regions of the 2005 BAF deposit contain areas a few meters in diameter consisting of a finergrained, well sorted ash. These areas have surficial multi-colored precipitate rings consisting of organic growth and mineral precipitants (white to orange to green from the center to the edge, but not all colors are present in every area). These circular

20 areas are interpreted to be the surface manifestations of degassing structures along the apex of deposit ridges. Plants $(<20 \mathrm{~cm}$ tall) have grown within a few meters of some of the degassing structures. The degassing structures have a higher thermal output than the surrounding deposit surface (warm to the touch), and one produced a tar smell (Figure 11). The hottest of these structures was $52^{\circ} \mathrm{C}$ on the surface and had a maximum temperature of $83^{\circ} \mathrm{C}$ at $16 \mathrm{~cm}$ depth. The temperature of the BAF deposit nearby (outside of the structure) at this time was $13^{\circ} \mathrm{C}$ at the surface down to $30 \mathrm{~cm}$. These temperatures were measured 
using an infrared thermometer in 2015 . Deposit temperatures of over $400^{\circ} \mathrm{C}$ were recorded at a depth of $167 \mathrm{~cm}$ in the first weeks after the deposit emplacement [Grishin, 2009].

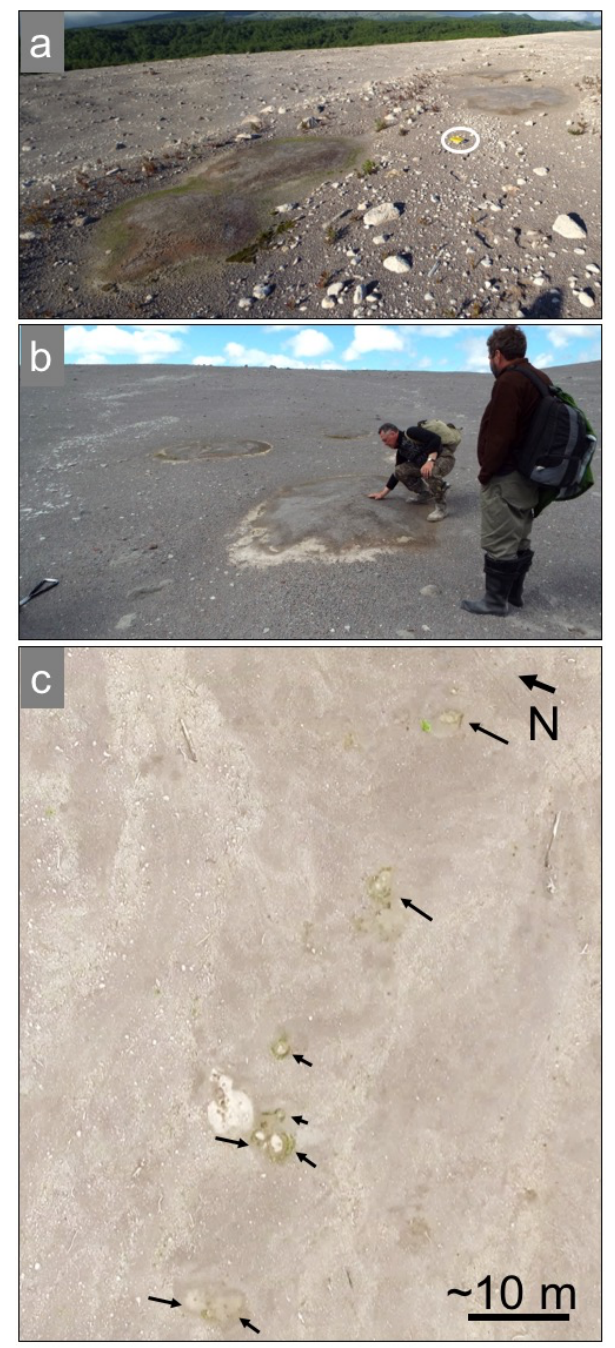

Figure 11 a-b) The surface manifestations of degassing structures along the thickest area of the 2005 BAF deposit, which is shown 5 in Figure 9, with surface discoloration and colored rings (field notebook is used for scale in the white circle); c) Plan-view drone image showing linear alignment of degassing structures (indicated by the black arrows) along the 2005 composite lobate feature. The degassing structures are of similar size to those in the photographs a-b. This location is given in Figure 3, box g.

\subsubsection{Surface block content}

Outsized blocks are scattered across the 2005 BAF deposit surface (Figure 12). The blocks are fragmented dome rock 10 characterized by various degrees of oxidation and banding with alternation of variously vesiculated material. Many blocks show evidence of clast interactions and stress during transport in the flow such as randomly-oriented impact marks (both elongate and rounded) and fracture networks. Some blocks are fractured to the extent that fragments can be broken off by hand (probably containing microfractures). 

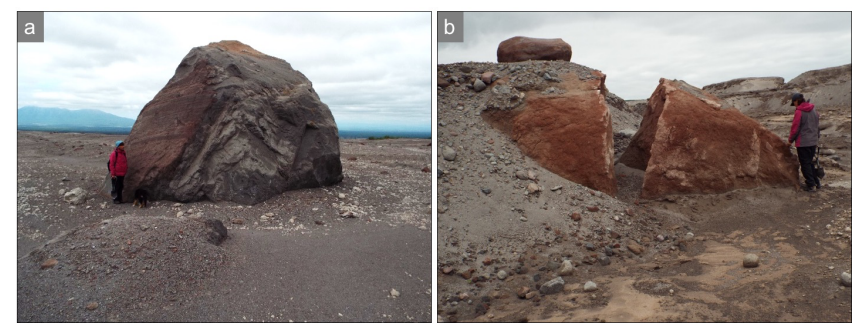

Figure 12. Large blocks of dome rock in the 2005 BAF deposit $12 \mathrm{~km}$ (a) and $15 \mathrm{~km}$ (b) from the dome base.

\subsubsection{Stratigraphic exposures}

Stratigraphic exposures in the 2005 BAF deposit reveal discontinuous units within the deposit (Figure 13). The

5 concentrations and sizes of larger blocks changes across short distances.

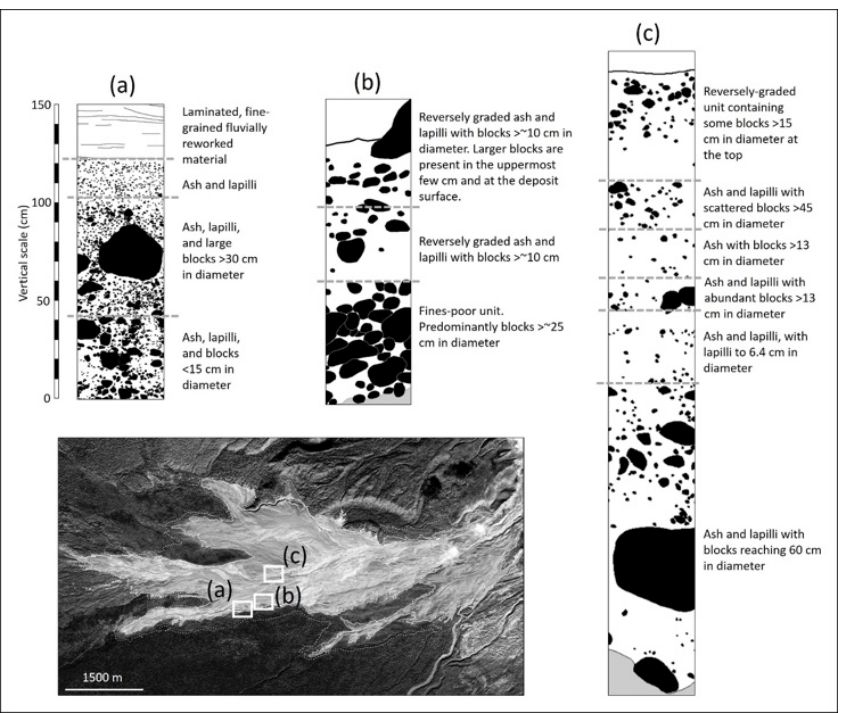

Figure 13. Three stratigraphic sections in the 2005 main deposit fan that show the discontinuous nature of the units within a $550 \mathrm{~m}$ distance.

Erosion along the southwestern lobe of the 2005 BAF deposit exposed a cross section of the distal part of the deposit

10 located $13 \mathrm{~km}$ from the dome. The BAF overlies a pyroclastic flow deposit that was emplaced $\sim 250$ BP [Ponomareva et al., 2007] (Figure 14). Here, the 2005 BAF deposit contains two distinct units separated by a sharp boundary. The lowermost unit is fines-poor, clast-supported, and has a thicker flow front. The upper unit is matrix-supported and consists of two sub-units with weak reverse grading. The base of a tree and its roots are also exposed here and is truncated at the contact between the two units, indicating that the tree was sheared off by the upper matrix-supported unit. 


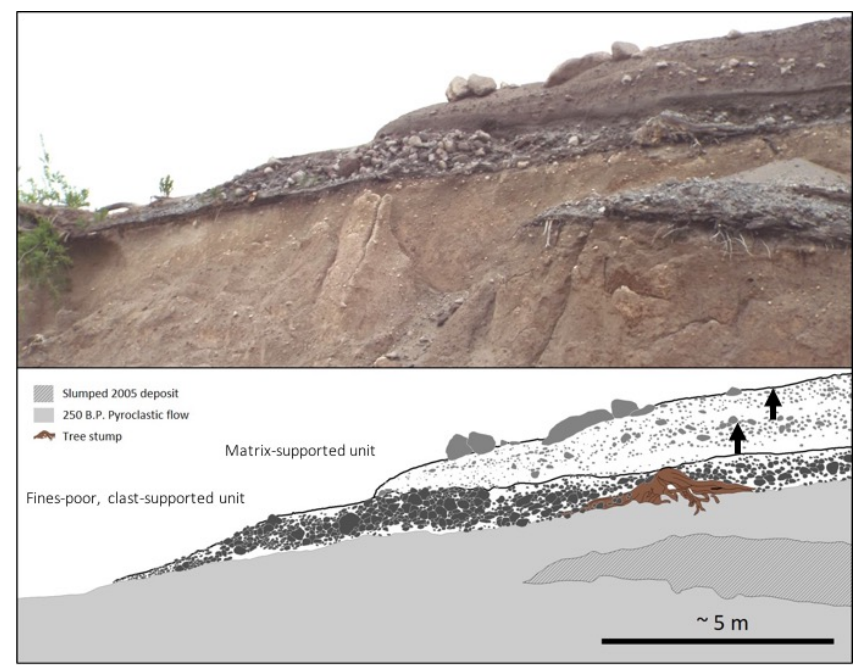

Figure 14. The distal end of a lobe located along the southern edge of the 2005 deposit with a fines-poor unit overlain by a matrixsupported unit. The two reversely-graded units are indicated by black arrows. This area is located in Figure 3, box $h$.

The largest vertical exposure through the 2005 deposit is along the northern margin of the 2005 main deposit fan 5 (Figure 15), where fluvial erosion has formed the new 25- to 50-m-wide by $>1 \mathrm{~km}$-long Baidarnaya River channel. Multiple stages of erosion cut terraces into the deposit in this area. On the southern wall of this channel, the river channel exposes a stratigraphic section of the deposit that is more than $20 \mathrm{~m}$ thick, whereas the northern wall of this channel is almost entirely composed of older pre-2005 deposit, including newly-dissected 7000-year-old maar deposits [Churikova et al., 2010]. Exposures near the distal end of the channel reveal a rapid thinning of the deposit towards its distal part.

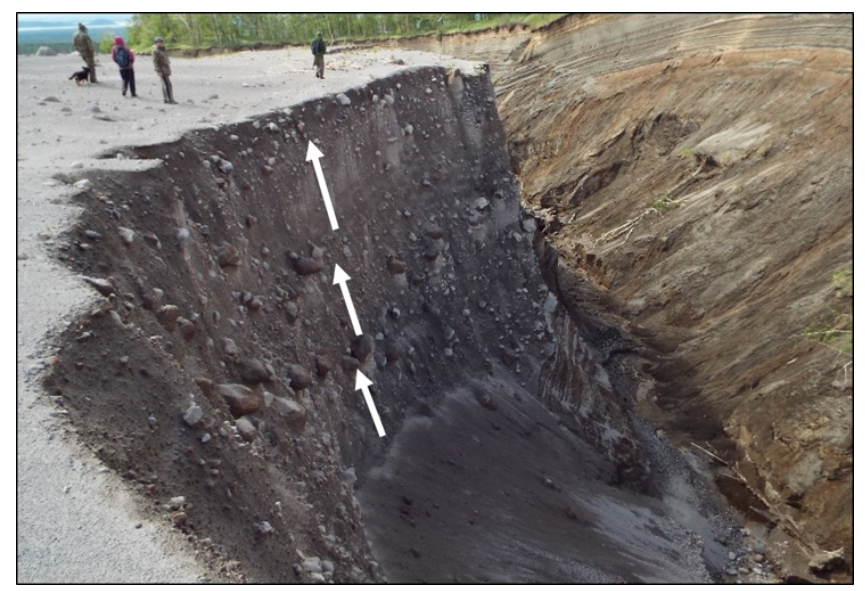

Figure 15. The cross section of the 2005 BAF deposit in the new channel cut by the post-2005 Baidarnaya River. Reversely-graded units are indicated by the white arrows pointing towards the coarser material. Note that no 2005 deposits are located on the right side of the channel where the BAF abuts to finely laminated deposits of a 7000 BP maar. The location of this photograph is indicated in Figure 3, box i. 
The October 2010 eruption and distribution of the resulting BAF deposit are described in Ovsyannikov and Manevich [2010], Shevchenko et al. [2015], and Krippner et al. [2018]. The following discussion focuses on the 2010 BAF main deposit fan and the channelized deposit that continued to the SE for $5.4 \mathrm{~km}$ beyond the distal edge of the fan. The locations of the

5 following figures are given in Figure 16.

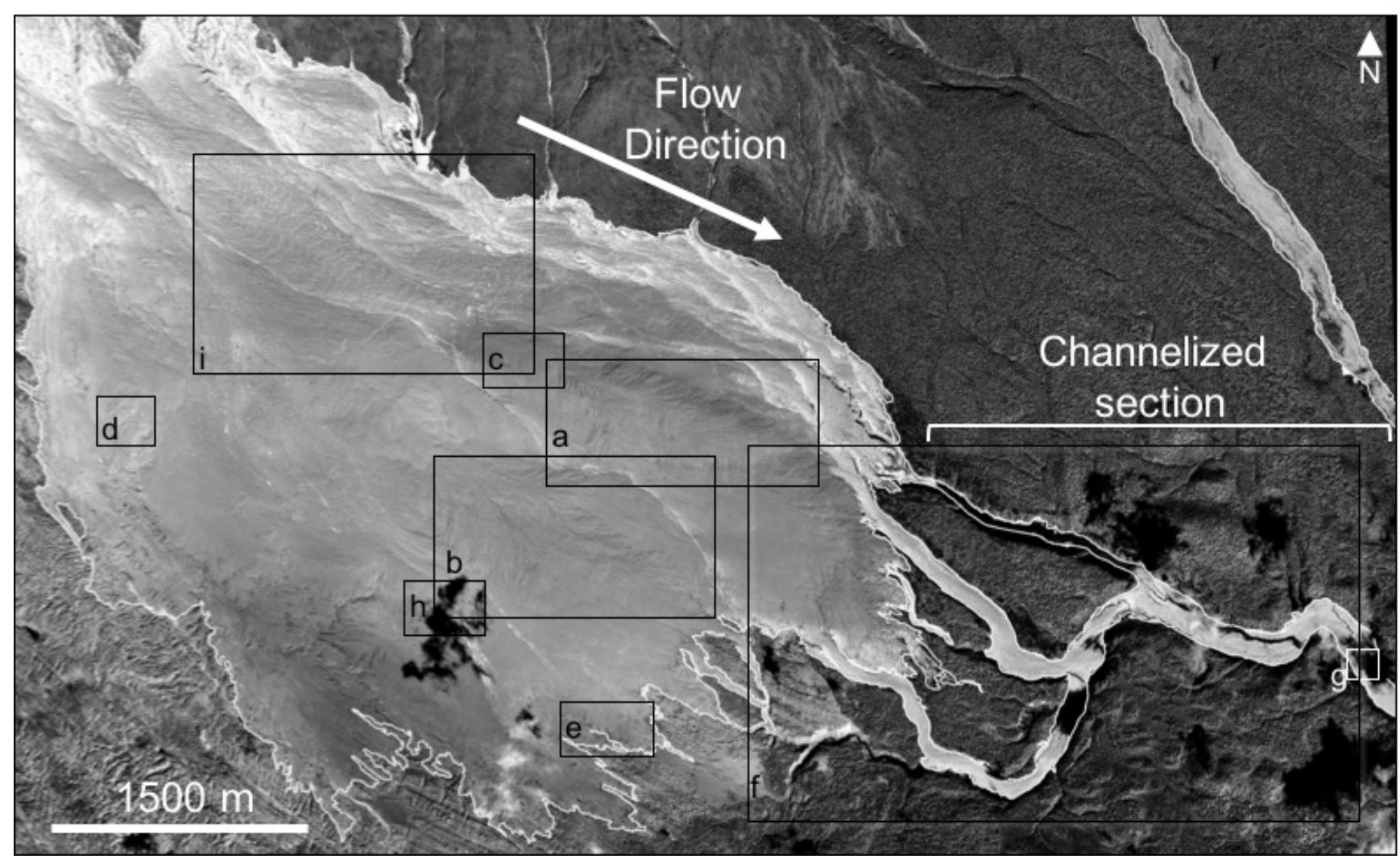

Figure 16. The Shiveluch 2010 BAF deposit main deposit fan and the channelized section that continued for an additional 5,400 m (panchromatic QuickBird-02 scene acquired on 27 August 2013). The white boxes and letters indicate the locations of photographs shown in the following section. The black boxes and letters indicate the areas of the figures that are enlargements of this WorldView02 scene in subsequent figures. a) Figure 17a, c; b) Figure 17b, d; c) Figure 18a d) Figure 18b; e) Figure 19; f) Figure 20; g) Figure 21; h) Figure 22 (WorldView-02 scene acquired on 19 March 2011 used in Figure 22 due to shadow in the 17 August 2013 scene); i) Figure 23.

The 2010 BAF main deposit fan covers an area of $16.2 \mathrm{~km}^{2}$. The geometric parameters of the deposit are summarized in Table 2. Approximately $9.5 \mathrm{~km}$ SE from the dome, the deposit surface contains two large composite lobate features with 15 differing flow lobe morphologies and overlapping relationships (the composite lobe class) (Figure 17). These two composite lobes vary in size (>750 m wide) and distance from the source (to $12 \mathrm{~km}$ ). Within these composite lobes, the largest singular lobes display dendritic ridge and furrow morphologies and some levee and channel features $>30 \mathrm{~m}$ wide. Most of the furrows and channels are filled with deposits of slightly younger flow pulses produced during the same eruption. In some areas, larger surface blocks are concentrated within these channels. The lobes vary in surface roughness, surface block concentrations, and 
the degree of toe development. Blocks of dome rock with diameters up to $7.5 \mathrm{~m}$ deposited at the distal reaches of the flow, at distances of $>12 \mathrm{~km}$ from the dome. The composite lobe surfaces contain arcuate scarps immediately upstream of areas containing rough deposit surfaces and of smaller lobes (arcuate scarp morphology). These are interpreted to be zones of shallow deposit remobilization.
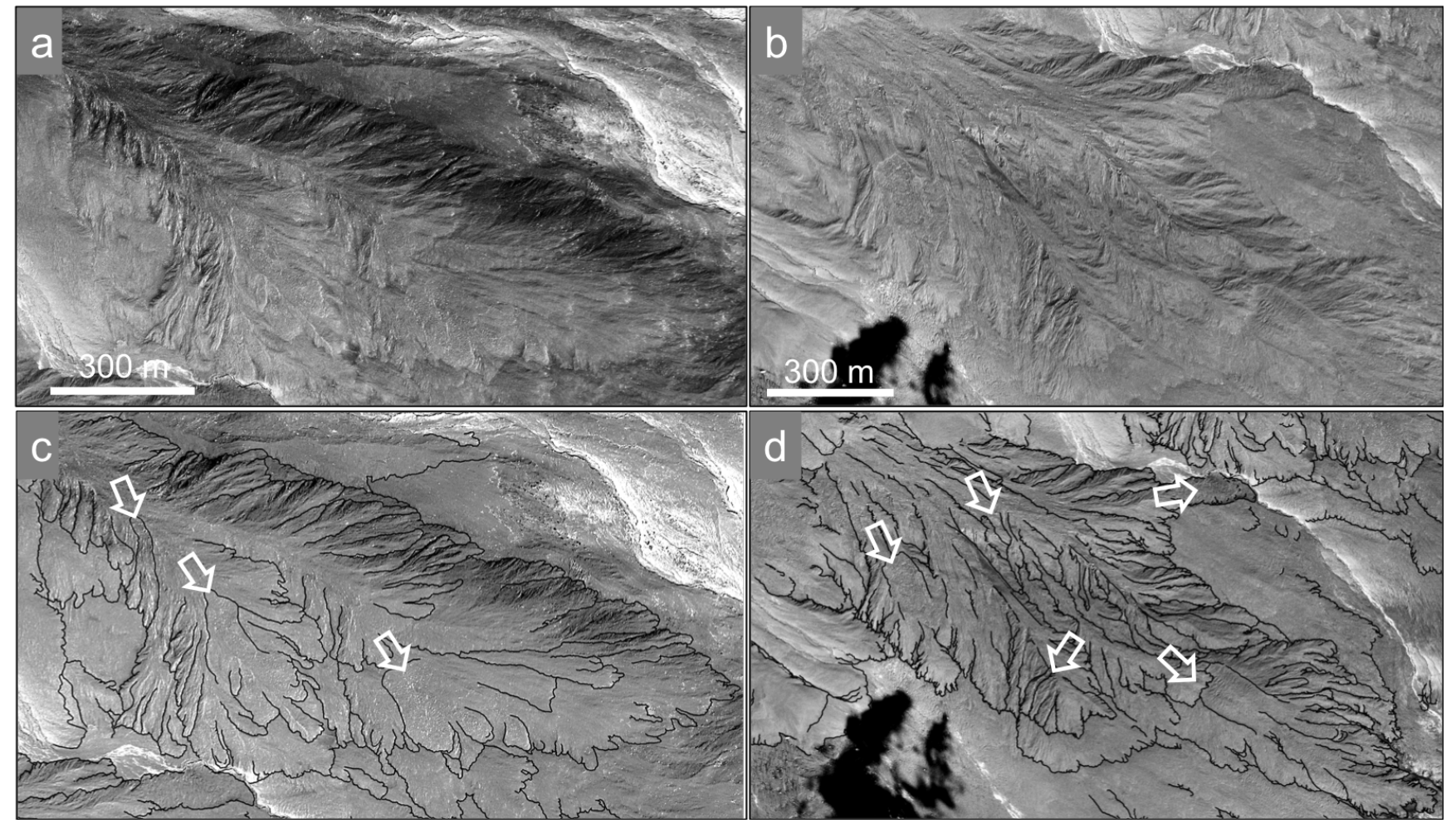

Figure 17. a) The 27 October 2010 BAF main deposit. Composite lobate morphologies are shown in b and $\mathbf{c}$ where black lines in d and $\mathrm{e}$ indicate the lobe fronts. The white arrows indicate the locations and directions of deposit remobilization. QuickBird-02 scene acquired on 27 August 2013. The location of these images are indicated in Figure 16 boxes a and b.

Evidence of the flow interacting with underlying topographic highs is present as the bifurcating flow and herringbone

10 morphology class described in Figure 2 (Figure 18), and material onlapping onto, or depositing around, the underlying 1964 debris avalanche deposit hummocks. The southern perimeter of the 2010 main deposit body has a higher proportion of the entrained vesicular andesite clasts of the 1964 pyroclastic flow deposit, within both sheet-like and elongate lobate deposits. The distal fan deposit area also contains elongate lobes (up to 130-m-wide but usually under 30-m-wide), which have diffuse feathery flow boundaries (Figure 19). The surfaces of these deposits have very few large blocks, only some of which are large 15 enough to be visible in the high-resolution satellite data. The feathery lobes deposited onto the underlying 1964 debris avalanche deposit and in places they were channelled into linear troughs [Belousov 1995; Belousov et al 1999]. 


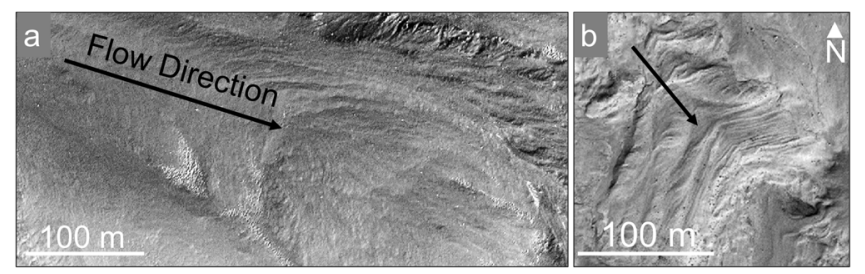

Figure 18. Herringbone structures on the 2010 deposit a) 8,000 $\mathrm{m}$ and b) 8,500 $\mathrm{m}$ from the dome (QuickBird-02 scene acquired on 27 August 2013). The location of these images are indicated in Figure 16, boxes c and d.

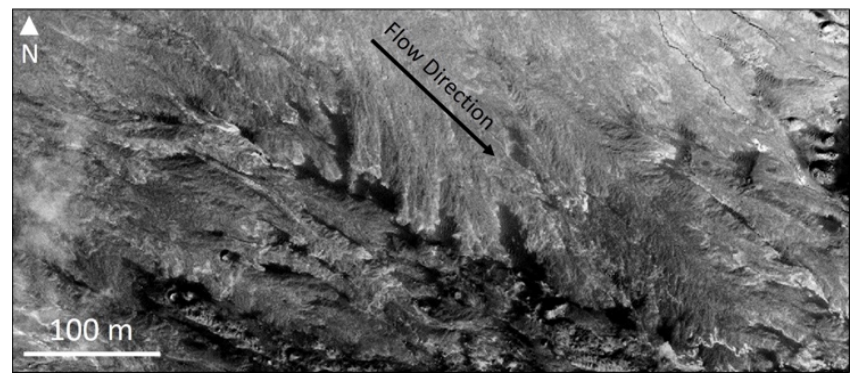

5 Figure 19. Feathery lobes in the 2010 deposit, 11,000 $\mathrm{m}$ from the dome. Here, the distal deposit was emplaced onto the hummocky 1964 debris avalanche deposit (QuickBird-02 scene acquired on 27 August 2013). The locations of these images are indicated in Figure 16, box e.

\subsubsection{Channelized deposit}

The 2010 BAF travelled down two river channels beyond the distal reach of the main BAF fan, converged into the

10 Kabeku River channel, and then flowed for an additional $5.4 \mathrm{~km}$ (Figure 20). Lobe and remobilization morphologies similar to those on the main deposit fan are present in this area as well. Arcuate scarp morphologies are present with irregular surfaces downstream of the scarps and lobate terminations. At a distance of $14 \mathrm{~km}$ from the dome, post-eruption river erosion exposed an outcrop through the entire length of the channelized deposit (Figure 21). The channel is up to $11 \mathrm{~m}$ deep, with over $6 \mathrm{~m}$ of deposit visible above the talus slope. The base of the channel is likely at or near the old channel bed. The deposit is massive,

15 poorly sorted, and matrix-supported. Some areas contain discontinuous horizontal concentrations of blocks. The lower few meters of the exposed deposit also contains a grey ash-rich matrix, whereas, the upper 90-100 cm contains a brown ash-rich matrix with a gradational boundary between the two subtle changes in color. This is likely due to the upper surface being oxidized by the high temperatures of the dome-rock. In one area, there is a horizontal section containing a higher concentration of subangular to subrounded blocks at the otherwise gradational boundary. The deposit with the grey ash-rich matrix appears

20 to contain a higher proportion of relatively large clasts up to $20 \mathrm{~cm}$ in diameter. The surface of the Kabeku River channel deposit contains areas of higher concentrations of 1964 vesicular andesite clasts than the main deposit fan, and variably-charred wood fragments emplaced as thin (one to ten $\mathrm{cm}$ thick) sheet-like deposits. 


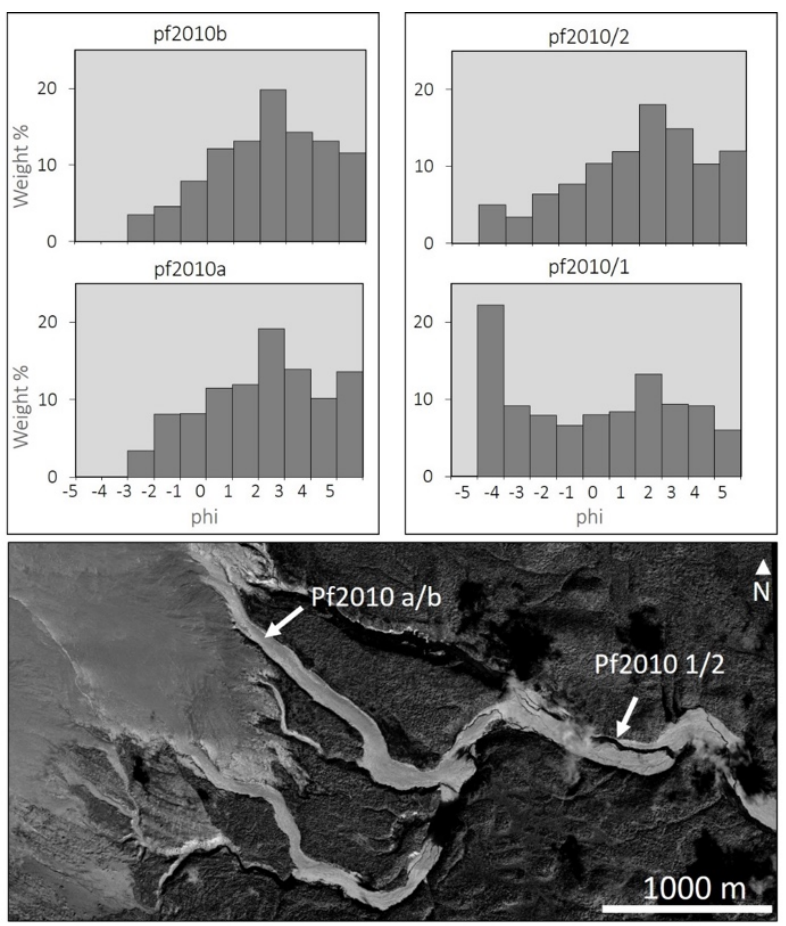

Figure 20. Grain-size distributions of the 2010 BAF deposit. The samples pf2010b and 2010/2 were overlying 2010a and 2010/1, respectively. Locations are shown on the QuickBird-02 scene below, acquired on 27 August 2013, and the location of this image is indicated in Figure 16, box $\mathrm{f}$.

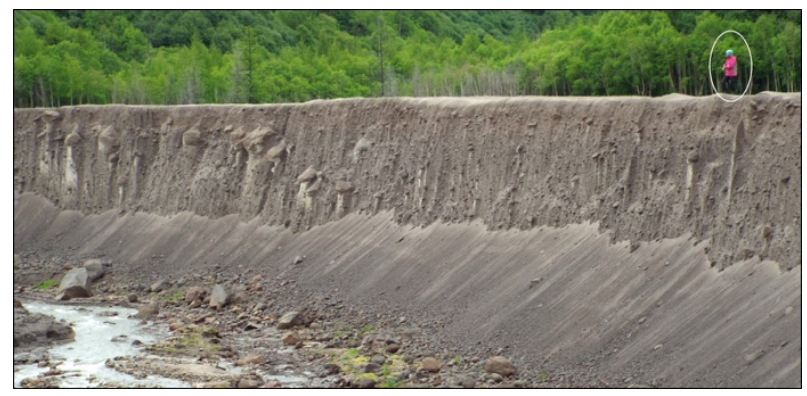

Figure 21. Cross section through the channelized 2010 BAF deposit $\sim 14 \mathrm{~km}$ from the dome, where the deposit is exposed down to the original riverbed surface. This outcrop location is indicated in Figure 16, box $\mathrm{g}$.

Along the upper valley of the Kabeku River channel, which is partly filled by the 2010 BAF deposit, the trees are scorched (blackened) and bent in the direction of flow, indicating the impact by an inflated zone of the high-temperature BAF.

10 The amount of damage to the vegetation within this channel varies locally, with damage ranging from felled trees (still attached to the tree-base) but no signs of burning, to carbonized and charred snags, to trees that are removed completely (no longer attached at the base). All of these various degrees of damage are present within a short distance of each other. The degree of damage to the bark varies from none, with the papery bark remaining, to completely stripped. Within a section of the newly eroded channel (down to the previous river bed) remaining tree stumps display no burning of the basal $\sim 0.5 \mathrm{~m}$, whereas the 
sections above this level are charred and then above this level, the top of the trees were removed completely at 2-3 m. Roots are exposed at the base of these trees.

\subsubsection{Ridges and scarps}

The area of the 2010 deposit shown in Figure 22 is located $\sim 9.7 \mathrm{~km}$ from the dome and contains multiple parallel

5 ridges perpendicular to flow direction. Here, the surface block abundance varies sharply within short distances. Several morphological classes are present in this area, indicating a rapid succession of BAF pulses, with the area labelled 'Ridges' in Figure 22 deposited first, and the block-rich and block-poor surfaces emplaced soon afterwards. The lowermost ridged deposit surface contains a moderate surface block content overlain by the $\sim 50 \mathrm{~m}$ long block-rich containing a much larger range of block sizes (up to $\sim 5 \mathrm{~m}$ in length). The uppermost block-poor deposit area has only a few scattered surface blocks to no surface

10 blocks present at all.

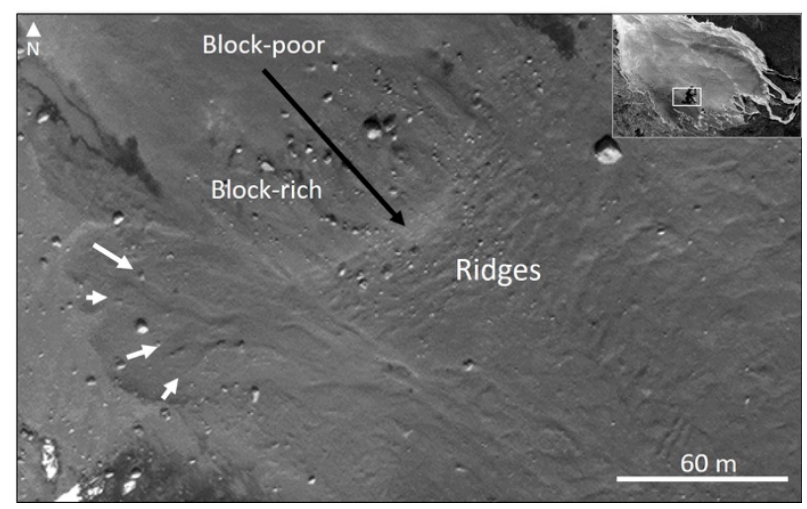

Figure 22. Varying block contents over a short distance with the smoother block-poor deposit surface in the upper left of the image. The black arrow indicates flow direction and the white arrows indicate deposit remobilization (QuickBird-02 scene acquired on 27 August 2013). This location is indicated in Figure 16, box $h$.

The bench and scallop or parallel linear scarp morphological class is common in the 2010 deposit. In the NE section of the 2010 BAF main deposit fan, there is a series of $\sim 30$ parallel benches up to $400 \mathrm{~m}$-wide, with a maximum spacing of 80 $\mathrm{m}$ between them (Figure 23). The lowermost bench is $1.8 \mathrm{~m}$ high. Field investigations revealed numerous degassing structures and small hummocks in this area. Narrower benches also occur to the west of this section. South of these benches, the scarps are more scalloped or arcuate in shape.

\section{$20 \quad$ 3.2.3 Degassing structures}

Degassing structure features are present on the surface of the 2010 deposit fan, and have the same characteristics as those described in the 2005 deposit. The features appear in clusters along the thickest areas of deposit and below the benches described in section 3.2.2. 


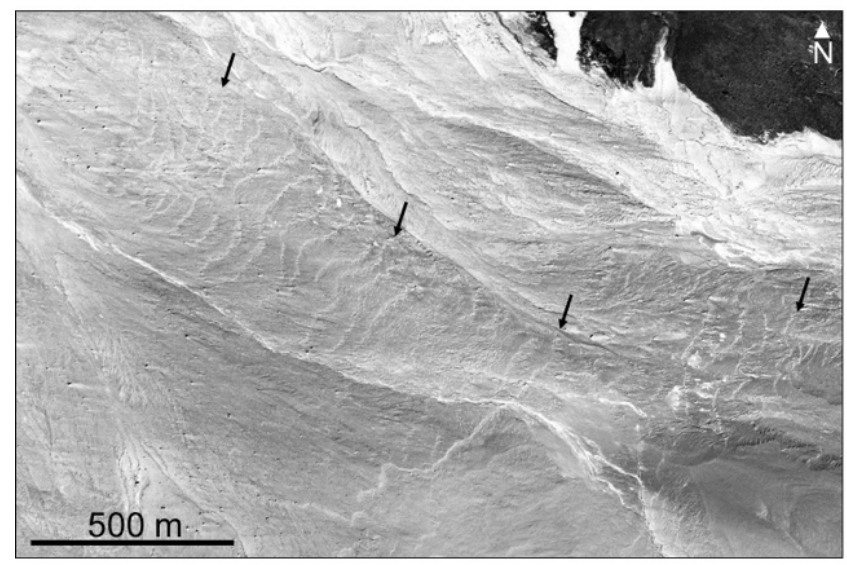

Figure 23. Bench and Scallop, or parallel linear scarp morphological class (area indicated in inset image) with black arrows indicating four out of the $\sim 30$ benches present. The black specks in the image are large blocks on the deposit surface. This location is indicated in Figure 16, box $\mathrm{i}$.

\section{3.2.4 Surface block content}

Outsized blocks up to $12 \mathrm{~m}$ in diameter litter the deposit surfaces of the 2010 BAF deposit (Figure 24). The blocks are composed of oxidized and texturally banded dome rock material. In the composite lobate areas, surface blocks are sometimes concentrated within the central channels of the channel and levee formations. Surface block abundance rapidly changes over a short distance. Impact marks (rounded and elongate) on the surfaces and fracture networks are common.

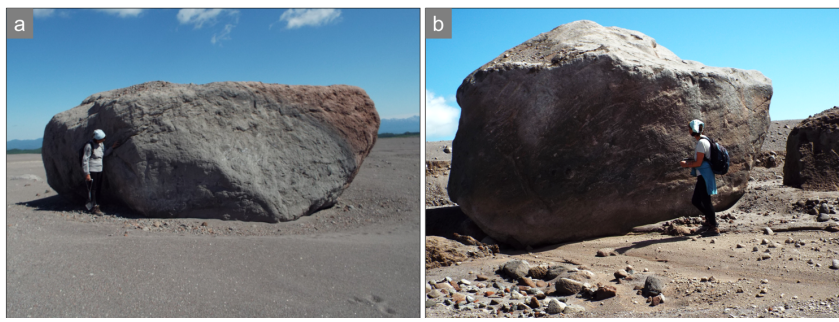

Figure 24. Large outsized blocks in the 2010 deposit a) $10 \mathrm{~km}$ from the dome base, and d) $13 \mathrm{~km}$ from the dome base.

\subsection{DiSCUSSION}

In this study, the surface morphology and lithology of the 2005 and 2010 BAF deposits and the accompanying pyroclastic surges are described using field and satellite data to explore the mechanisms of their formation and emplacement,

15 and the impacts on the local vegetation. The parameters of the 2005 and 2010 BAF deposits are summarized in Table 2. The current dome at Shiveluch volcano has been growing since 1980 [Dvigalo, 1988, Gorelchik et al., 1997; Dirksen et al., 2006; Zharinov and Demyanchuk, 2008; Gorbach and Portnyagin, 2011; Ponomavera et al., 2013; Shevchenko et al., 2015] and before the 2005 and 2010 collapses, the dome reached volumes/relative elevations of $>0.47 \mathrm{~km}^{3} / 517 \mathrm{~m}$ and $0.54 \mathrm{~km}^{3} / 563 \mathrm{~m}$, respectively (Table 2). Intrusions of new magma and the accompanying explosive activity destabilize the growing dome

20 leading to gravitational collapse events. The 2005 and 2010 BAF deposits and the corresponding collapse scars on the dome surface were produced during eruptive episodes lasting 6-8 hours [Ovsyannikov and Manevich, 2010, Kamchatka Volcanic 
Eruption Response Team (KVERT) report 28 October 2010]. These deposits are primarily composed of fragmented heterogeneous dome material. There is no evidence (e.g., breadcrust bombs and/or highly vesicular juvenile material) that the collapses involved still-ductile dome rock and/or magma from deeper levels of the volcano conduit. The deposit composition, together with the surface morphologies and volumes of the post-eruptive scars at the dome surface, indicate that the BAFs

5 were formed during the process of large-volume gravitational collapses of the growing lava dome.

Such blocks continue to fail over periods of hours during the eruptions. Each complex retrogressive failure episode produced multiple BAF pulses that form a singular large eruption deposit (different flow pulses originate from different collapsed blocks). These pulses are recognized on the basis of deposit stratigraphy, varying surface block contents and differing surface morphologies (Figure 22). The locations of stacked, multiple reversely-graded units coincide with areas of overlapping

10 lobate deposit, and the areas lacking internal structure coincide with the areas lacking such surface features. The concentrations of large dome blocks differ in onlapping sections of the deposit, indicating different degrees of fragmentation of the dome material in subsequent dome collapses. Different degrees of fragmentation likely represent different areas inside the dome such as hot, more gas-rich inner, younger parts of the dome, and the outer, older, cooler, degassed dome carapace. The variations in surface block abundance across similar distances from the dome show differences in the ability of dome rock to

15 break apart during the collapse and transportation. The blocks travelling the same distance over the same or very similar surfaces implies the cause for the variations in size and concentration are heterogeneity the collapsing dome rock. The areas containing higher concentrations of large dome blocks likely originate from areas of the dome that have undergone higher degrees of cooling and degassing (outer and/or older areas of the dome). Areas lacking surface dome blocks are likely from the more hot and gas-rich areas of the dome, resulting in more extensive fragmentation due to gas-related autobrecciation 20 during transport.

These events were not directly observed but similar events, although of smaller-volumes, were recorded several times by a webcam installed by the Kamchatka Volcano Observatory. This camera documented three large energetic pulses of BAF on December 3, 2013 that occurred over several hours, reaching $13.6 \mathrm{~km}$ from the dome [Krippner et al., 2018]. These pulsatory retrogressive dome collapse events are common at a large domes of viscous lava [Cole et al., 1998; Calder et al., 1999; Calder et al., 2002; Cole et al., 2002; Charbonnier, and Gertisser, 2009; Charbonnier et al., 2012].

BAFs are unsteady pyroclastic density currents with instabilities that originate both from the source via unsteady collapse [Cole et al., 2002; Loughlin et al., 2002], and from the development of kinematic waves that have been described for BAFs and debris flows [Iverson, 1997; Schwarzkopf et al., 2005]. It is likely that both of these processes occurred during the 2005 and 2010 Shiveluch BAF deposits as evidenced by the different scales of morphological features and the striking 30 differences in concentrations of large surface blocks. The presence of rounded and elongate impact marks on the surfaces of boulders indicate both collisional and longer-duration frictional interactions during the dome collapse and the following transportation in BAF [Dennen et al., 2014]. Rare elongate impact marks show evidence for impact-induced melting with an outer glassy (psudotachylite) layer. This is also seen on blocks in other BAF deposits such as the 1998 deposits at Merapi volcano, and in the 1995-1999 deposits at Soufriere Hills [Grunewald et al., 2000; Schwarzkopf et al., 2001]. 
Channel and levee structures (dominantly occurring in the 2010 deposit) indicate that the system formed as a result of levee breakouts, similar to levee breaches seen on the Mount St. Helens ignimbrite fan [Branney and Kokelaar, 2002]. Ridge and furrow structures, along with the concentration of low density material at deposit margins, was also described by Cole et al. [2002] in the areas covered by unconfined BAF deposits of the Soufriere Hills 1995-1998 eruption. The authors attribute

5 this to: (1) the flow front entraining low-density material (which concentrates towards the upper surface and front of the flow); (2) the lower flow region decelerating and emplacing material, with the overlying material continuing to propagate forward; and (3) the final deposit being emplaced such that material is stranded on large blocks. Such a transport model can also be applied to the Shiveluch BAFs. In addition, and similar to, the BAFs at Merapi volcano [Schwarzkopf et al., 2001], the features described here indicate that the 2005 and 2010 Shiveluch BAFs were unsteady granular flows that deposited starting at the

10 flow front and progressing rearward and simultaneously upward from the flow base. Evidence for this process is seen in unusual detail in these deposits due to the highly erosive flows entraining significant amounts of 1964 pyroclastic flow material. Bands enriched with the lower-density 1964 andesite clasts are present on the deposit sections emplaced during different stages throughout the eruption (as seen by the superposition of lobes). This suggests that substrate entrainment occurred throughout the eruption course, even as the flow was waning, to produce shorter runout distances that emplaced material towards the rear 15 of the thickening deposit (Figure 8).

The extended channelized section of the 2010 deposit was emplaced before the final stages of emplacement of the major fan of the deposit. Prior to the 2010 event, the Kabeku River channel extended much closer to the dome, providing a large distance (over $7 \mathrm{~km}$ ) where the flow may have entered the channel. The point of entry is no longer visible with deposition covering the channel entrance. The channelized section is determined to be primary (not remobilized material) due to: 1) the

20 lobes present on the surface that are not emanating from a scarp source, 2) the presence of small hummocks that are also seen in the main deposit fan area, 3) the remobilized deposit features on the deposit surface, 4) the subsequent deposition of BAF material in the main deposit fan area, and 5) the trees that were killed and bent towards the direction of flow up the Kabeku River channel walls above the deposit surface, probably from an overriding ash (co-ignimbrite-type) plume. The channelized section of the 2010 deposit also shows evidence for unsteady flow behavior through localized changes in tree damage. Exposed

25 tree snags within the eroded channel sustained burning to the top of the trees, but none at the base. This could be due to the initial pulses of flow mixing with snow and ice, cooling the rock before the flow got to this point, $>15 \mathrm{~km}$ away from the dome. Subsequent flow pulses may have then moved over the that deposit retaining more heat. Alternatively, the initial pulses of the flow comprised a large volume of the outer cooler carapace of the dome, and later pulses incorporated a larger proportion of the inner hot dome material.

Syn- or post-depositional remobilized surface features are preserved in the deposit surfaces and three morphologies are descrived: 1) parallel linear scarp, 2) arcuate scarp, and 3) curvilinear bench and scarp morphology. Secondary lobate deposits occur below the arcuate scarp, and scarp and bench areas, both in the main deposit fans and the 2010 channelized deposit section. During or soon after deposition (while subsequent material was still being transported and emplaced) portions of these thick lobes were transported forward, forming deposits that continued for over $500 \mathrm{~m}$ from the scarps, and terminated 35 either in lobate deposits similar to the primary deposition features or in more rounded bulbous lobes with several ridges parallel 
to the lobe front. The areas downflow from these scarps are typically rough compared to the smoother primary deposit surfaces, and they contain short (meters-wide) ridges that are aligned perpendicular to flow direction. Direct evidence for syndepositional remobilization is seen in the 2010 deposit, where one of the earlier lobes shows evidence of remobilization through the ridged surface, scarp flanks, and new lobes emanating from these areas (Figure 17). These syn-depositional features

5 indicate that freshly emplaced BAF deposits had low coefficient of internal friction due to high content of residual gas. Evidence for high gas content is also shown by the presence of degassing structures on the deposit surfaces. Secondary pyroclastic density currents (formed by remobilization of freshly emplaced material) are also noted in the 12 June 1980 Mount St. Helens pumice plain hours after the eruption, and within the 1991 Pinatubo ignimbrite deposits for as long as two years after emplacement [Rowley et al., 1981; Torres et al., 1996].

It is the preservation of these deposits and the vertical exposures exposing the stratigraphy of these deposits that provide evidence of the dome collapse, transportation, deposition, and post-emplacement processes of large dome-collapse BAFs.

\subsection{CONCLUSIONS}

The Shiveluch 27-28 February 2005 and 28 October 2010 BAF deposits were produced by two of the largest historical

15 dome-collapse events on Earth, providing extreme end members for dome-collapse product distributions. Each of these dome collapse events occurred in multiple phases within eruption episodes occurring over hours and produced a single large deposit composed of lobate fans with variable surface block contents (that in cross sections formed discontinuous flow units). Surface morphologies and internal deposit structure are described in detail, enabled by the incised channels coupled with surface preservation that is not common in BAF deposits.

Future field investigations of BAF deposits in areas with partially exposed or preserved deposits should be aware that discontinuous flow units can be emplaced during episodes that produce multiple collapse events. Thus, where studying older deposits in the field, it should be noted that: (a) stratigraphic subunits within large BAFs are discontinuous and therefore may be completely lacking in some areas (so may easily be missed), and (b) if reversely-graded units are visible in cross-sections they may be interpreted as smaller BAF events, but they could be part of a much larger eruption deposit containing multiple

25 subunits. This has implications for determining the eruption history at volcanoes where individual eruption size is being determined in order to estimate future volcanic hazards and the distribution and magnitude of potential eruptions.

\section{AUTHOR CONTRIBUTIONS}

Satellite analyses and manuscript writing were carried out by Janine Krippner. Field work and field interpretations were done by Janine Krippner, Alexander Belousov, and Marina Belousova. Drone flights were performed by Alexander Belousov. Grain

30 size analyses were carried out by Marina Belousova. Initial funding support and graduate supervision were done by Michael Ramsey.

\section{ACKNOWLEDGEMENTS}

Initial funding for this work was provided by NASA (grant \# NNX14AQ96G), followed by a NASA Earth and Space Science Fellowship (2014-15, 2015-16, 2016-17), a Henry Leighton Memorial Graduate Scholarship, University of Pittsburgh Hewlett

35 International Grant, University of Pittsburgh International Studies Fund, and GSA (The Geological Society of America) 
Graduate Student Research Grant. The high-resolution QuickBird-02 and WorldView-02 data were provided by a DigitalGlobe Foundation Imagery Grant. Thank you to Alison Graettinger and John Pallister for comments and discussions.

\section{REFERENCES}

5 Belousov A.B. (1995) The Shiveluch volcanic eruption of 12 November 1964 - explosive eruption provoked by failure of the edifice. Journal of Volcanology and Geothermal Research 66: 357-365.

Belousov A., Belousova M., Voight B. (1999) Multiple edifice failures, debris avalanches and associated eruptions in the Holocene history of Shiveluch volcano, Kamchatka, Russia. Bulletin of Volcanology 61:324-342.

10

Branney, M.J., Kokelaar, P., 2002. Pyroclastic Density Currents and the Sedimentation of Ignimbrites. Geological Society of London Memoirs, 27.

Bursik, M., Patra, A., Pitman, E.B., Nichita, C., Macias, J.L., Saucedo, R. and Girina, O., 2005. Advances in studies of dense volcanic granular flows. Reports on Progress in Physics, 68: 271-301.

Calder, E.S., Cole, P.D., Dade, W.B., Druitt, T.H., Hoblitt, R.P., Huppert, H.E., Ritchie, L., Sparks. R.S.J., Young. S.R., 1999. Mobility of pyroclastic flows and surges at the Soufriere Hills Volcano, Montserrat. Geophysical Research Letters, 26(5): 537540.

Calder, E.S., Luckett, R., Sparks, R.S.J., Voight, B., 2002. Mechanisms of lava dome instability and generation of rockfalls and pyroclastic flows at Soufrire Hills Volcano, Montserrat. In Druitt, T. H. \& Kokelaar, B. P. (eds) 2002. The Eruption of Soufriere Hills Volcano, Montserrat, from 1995 to 1999. Geological Society, London, Memoirs, 21, 191-209. 0435$4052 / 02 / \$ 15$

Carn, S.A., Watts, R.B., Thompson, G., Norton, G.E., 2004. Anatomy of a lava dome collapse: the 20 March 2000 event at Soufriere Hills Volcano, Montserrat. Journal of Volcanology and Geothermal Research, 131: 241-264.

Carter, A., Ramsey, M., 2010. Long-term volcanic activity at Shilveluch volcano: nine year of ASTER spaceborne thermal infrared observations. Remote Sensing, 2:2571-2583. doi:10.3390/rs2112571.

Charbonnier, S.J., Gertisser, R., 2009. Numerical simulations of block-and-ash flows using the Titan2D flow model: examples from the 2006 eruption of Merapi Volcano, Java, Indonesia. Bulletin of Volcanology, 71:953-959.

Charbonnier, S.J., Gertisser, R., 2011. Deposit architecture and dynamics of the 2006 block-and-ash flows of Merapi Volcano, 35 Java, Indonesia. Sedimentology, 58: 1573-1612. 
Charbonnier, S.J., Germa, A., Connor, C.B., Gertisser, R., Preece, K., Komorowski, J.-C., Lavigne, F., Dixon, T., Connor, L., 2013. Evaluation of the impact of the 2010 pyroclastic density currents at Merapi volcano from high-resolution satellite imagery, field investigations and numerical simulations. Journal of Volcanology and Geothermal Research, 261, 295-315. doi: $5 \quad$ 10.1016/j.jvolgeores.2012.12.021.

Churikova, T. G., Gordeychik, B. N., Belousov, A. B. \& Babansky, A. D., 2010. Finding of the centre of the eruption of basalts on the volcano Shiveluch. Materials of Conference Dedicated to the 75th Anniversary of the Kamchatka Volcanological Station: Petropavlovsk-Kamchatsky, September 9-15, $2010 \quad$ (ed. Gordeev, E. I.) (In Russian). 10 http://www.kscnet.ru/ivs/slsecret/75-KVS/ Material_conferenc/art25.pdf (IViS FEB RAS, 2010).

Cole, P.D., Calder, E.S., Druitt, T.H., Hoblitt, R., Robertson, R., Sparks, R.J.S., Young, S.R., 1998. Pyroclastic flows generated by gravitational instability of the 1996-97 lava dome of Soufriere Hills Volcano, Montserrat. Geophysical Research Letters, 25(18): 3425-3428.

15

Cole, P.D., Calder, E.S., Sparks, R.S.J., Clarke, A.B., Druitt, T.H., Young, S.R., Herd, R.A., Haford, C.L., Norton, G.E., 2002. Deposits from dome-collapse and fountain-collapse pyroclastic flows at Soufrière Hills Volcano, Montserrat. In Druitt, T. H. \& Kokelaar, B. P. (eds) 2002. The Eruption of Soufriere Hills Volcano, Montserrat, from 1995 to 1999. Geological Society, London, Memoirs, 21, 191-209. 0435-4052/02/\$15.

Cronin, S.J., Lube, G., Dayudi, D.S., Sumatri, S., Subrandiyo, S., Surono, 2013. Insights into the October-November 2010 Gunung Merapi eruption (Central Java, Indonesia) from the stratigraphy, volume and characteristics of its pyroclastic deposits. Journal of Volcanology and Geothermal Research, 261:244-259.

25 Dellino, P., La Volpe, L., 1995. Fragmentation versus transportation mechanisms in the pyroclastic sequence of Monte PilatoRocche Rosse (Lipari, Italy). Journal of Volcanology and Geothermal Research, 64: 211:231.

Dennen, R.L., Bursik, M.I., Roche, O., 2014. Dome collapse mechanisms and block-and-ash flow emplacement dynamics inferred from deposit and impact mark analysis, Mono Craters, CA. Journal of Volcanology and Geothermal Research, 276: $1-9$.

Dirksen, O., Humphreys, M.C.S., Pletchov, P., Melnik, O., Demyanchuk, Y., Sparks, R.S.J., Mahony, S., 2006. The 20012004 dome-forming eruption of Shiveluch volcano, Kamchatka: Observation, petrological investigation and numerical modelling. Journal of Volcanology and Geothermal Research, 155: 201-266. 
Dvigalo, V.N., 1988. Growth of a dome in the crater of Shiveluch Volcano in 1980-1981 from photogrammetry data. Journal of Volcanology and Seismology, 6:307-315.

Dvigalo, V.N., Svirid, I.Yu, Shevchenko, A.V., Sokorenko, A.V., Demyanchuk, Yu.V., 2011. Active volcanoes of northern 5 Kamchatka as seen from aerophotogrammetric data in 2010. Proceedings of regional conference "Volcanism and associated processes”. Institute of Volcanology and Seismology FEB RAS, Petropavlovsk-Kamchatsky, pp. 26-36 (in Russian).

Fedotov, S.A., Dvigalo, V.N., Zharinov, N. A., Ivanov, V. V., Seliverstov, N. I., Khubunaya, S. A., Demyanchuk, Yu. V., Markov I. A., Osipenko, L. G., Smelov, N. P., 2001. Eruption of Shiveluch volcano in May-July 2001. Journal of Volcanology 10 and Seismology, 6:3-15. (In Russian).

Fedotov, S.A., Zharinov, N.A., Dvigalo, V.N., Seliverstov, N.I. and Khubunaya, S.A., 2004. The 2001-2004 eruptive cycle of Shiveluch Volcano. Journal of Volcanology and Seismology, 6: 3-14.

15 Glicken, H. 1996. Rockslide-debris Avalanche of May 18, 1980, Mount St. Helens Volcano, Washington: U.S. Geological Survey Open-File Report 96-677, https://pubs.usgs.gov/of/1996/0677/.

Girina, O.A., Demyanchuk, Yu.V., Melnikov, D.V., Ushakov, S.V., Ovsyannikov, A.A., Sokorenko, A.V., 2006. The paroxysmal phase during the eruption of Molodoi Shiveluch Volcano, Kamchatka, February 27, 2005 (preliminary report), Journal of Volcanology and Seismology, 1: 16-23.

Girina, O.A., Senyukov, S.L., Demyunchuk, Y.V., Khubunaya, S.A., Ushakov, S.V., 2004. The eruption of Sheveluch volcano, Kamchatka, on May 10, 2004. IV International Biennial Workshop on Subduction Processes emphasizing the Japan-KurileKamchatka-Aleutian Arcs, Petropavlovsk- Kamchatsky.

Girina, O.A., Manevich, A.G., Malik, N.A., Mel'nikov, D.V., Ushakov, S.V., Demyanchuk, Y.U. and Kotenko, V., 2007. Active volcanoes of Kamchatka and northern Kurils in 2005. Journal of Volcanology and Seismology, 1(4): 237-347.

Gorbach, N.V., 2006. Extrusive dome formation at Shiveluch Volcano and its lava composition in 2004-2005. Proceedings 30 of international symposium "Problems of explosive volcanism". Institute of Volcanology and Seismology FEB RAS, Petropavlovsk- Kamchatsky, pp. 112-119 (in Russian).

Gorbach, N.V., Portnyagin, M.V., 2011. Geology and Petrology of the Lava Complex of Young Shiveluch Volcano, Kamchatka. Petrology, 19(2): 134-166. 
Gorbach, N.V., Plechova, A.A., Ponomareva, V.V., Tembrel, I.I., 2013. The explosive Shiveluch eruption of July $26,2013$. Bulletin of Kamchatka Association "Educational-Scientific Center" 2: 15-19.

Gorbach, N.V., Portnyagin, M.V., Philosofova, T.M., 2016. Dynamics of Extrusive Dome Growth and Variations in Chemical 5 and Mineralogical Composition of Young Shiveluch Andesites in 2001-2013. Journal of Volcanology and Seismology, 10(6): $360-381$.

Gorelchik, V.I., Shirokov, V.A., Firstov, P.P., Chubarova, O.S., 1997. Shiveluch volcano: seismicity, deep structure and forecasting eruptions (Kamchatka). Journal of Volcanology and Geothermal Research, 78:121-132.

10

Grishin, S.Yu., 2009. Forest Die-Off under the Impact of Burning Pyroclastic Surge on the Shiveluch Volcano (Kamchatka, 2005). Russian Journal of Ecology, 40(2): 146-148.

Grishin, S.Yu., 2012. Colonizing Plants on Hot Pyroclastic Flow Deposits (Shiveluch Volcano, Kamchatka). Russian Journal 15 of Ecology, 43(2): 174-176.

Grunewald, U., Sparks, R.S.J., Kearns, S., Komorowski, J.C., 2000. Friction marks on blocks from pyroclastic flows at the Soufriere Hills volcano, Montserrat: Implications for flow mechanisms. Geology, 28(9):827-830.

20 Herd, R.A., Edmonds, M., Bass, V.A., 2005. Catastrophic lava dome failure at Soufrière Hills Volcano, Montserrat, 12-13 July 2003. Journal of Volcanology and Geothermal Research, 148: 234-252.

Ivanov B.V., Chirkov A.M., Dubik Yu.M. et al (1981) Activity of volcanoes of Kamchatka in 1980. Volcanology and Seismology 3: 99-104 (in Russian)

25

Iverson, R., 1997. The physics of debris flows. Reviews of Geophysics, 35(3): 245-296.

Krippner, J.B., Belousov, A.B., Belousova, M., Ramsey, M., 2018. Parametric analysis of lava dome-collapse events and pyroclastic deposits at Shiveluch volcano, Kamchatka, using visible and infrared satellite data. Journal of Volcanology and Geothermal Research, 354: 115-129.

Loughlin, S.C., Calder, E.S., Clarke, A., Cole, P.D., Luckett, R., Mangan, M.T., Pyle, D.M., Sparks, R.S.J., Voight, B., Watts, R.B., 2002. Pyroclastic flows and surges generated by the 25 June 1997 dome collapse, Soufriere Hills Volcano, Montserrat. In Druitt, T. H. \& Kokelaar, B. P. (eds) 2002. The Eruption of Soufriere Hills Volcano, Montserrat, from 1995 to 1999. 35 Geological Society, London, Memoirs, 21, 191-209. 0435-4052/02/\$15 
Mackaman-Lofland, C., Brand, B.D., Taddeucci, J., Wohletz, K., 2014. Sequential fragmentation/transport theory, pyroclast size-density relationships, and the emplacement dynamics of pyroclastic density currents - A case study on the Mt. St. Helens (USA) 1980 eruption. Journal of Volcanology and Geothermal Research, 275: 1-13.

Ormas-Dorta, D., Cole, P.D., Wadge, G., Alvarado, G.E., Soto, G.J., 2012. Spatial and temporal controls on pyroclastic flow hazard at Arenal volcano, Costa Rica. Journal of Volcanology and Geothermal Research, 225-226: 45-64.

Ovsyannikov, A., Manevich, A., 2010, Eruption Shiveluch in October 2010, Bulletin of Kamchatka Regional Association 10 (Educational-Scientific Center); Earth Sciences (in Russian), IV\&S FEB RAS, Petropavlovsk-Kamchatsky, 2010, 2(16), ISSN 1816-5532.

Ponomareva, V., Kyle, P. Pevzner, M., Sulerzhitsky, L., Hartman, M., 2013. Holocene Eruptive History of Shiveluch Volcano, Kamchatka Peninsula, Russia. In Volcanism and Subduction: The Kamchatka Region (eds J. Eichelberger, E. Gordeev, P. 15 Izbekov, M. Kasahara and J. Lees). doi:10.1029/172GM19.

Ramsey, M.S., 2016. Synergistic use of satellite thermal detection and science: A decadal perspective using ASTER, in Harris, A.J.L., De Groeve, T., Garel, F., Carn, S.A. [Eds.]. Detecting, Modelling and Responding to Effusive Eruptions. Geological Society London Special Publication 426, doi:10.1144/SP426.23, pp. 115-136.

Rowley, P.D., Kuntz, M.A., MacLeod, 1981. Pyroclastic-flow deposits, in Lipman, P.W., Mullineaux, D.R., [Eds.]. The 1980 eruptions of Mount St. Helens, Washington. US Geological Survey Professional Paper 1250, pp. 489-512.

Schwarzkopf, L.M., Schmincke, H.-U., Troll, V.R., 2001. Pseudotachylite on impact marks of block surfaces in block-andash flows at Merapi volcano, Central Java, Indonesia. International Journal of Earth Sciences, 90(4): 769-775.

Schwarzkopf, L.M., Schmincke, H.-U., Cronin, S.J., 2005. A conceptual model for block-and-ash flow basal avalanche transport and deposition, based on deposit architecture of 1998 and 1994 Merapi flows. Journal of Volcanology and Geothermal Research, 139: 117.

Shevchenko, A.V., Svirid, I. Yu, 2014. Collapsing processes of the current lava dome at Molodoy Shiveluch Volcano. Proceedings of the XIII regional youth conference "The natural environment of Kamchatka". Institute of Volcanology and Seismology FEB RAS, Petropavlovsk-Kamchatsky, pp. 129-142 (in Russian). 
Shevchenko, A.V., Dvigalo, V.N., Svirid, I.Y., 2015. Airborne photogrammetry and geomorphological analysis of the 20012012 exogenous dome growth at Molodoy Shiveluch Volcano, Kamchatka. Journal of Volcanology and Geothermal Research, 304: 94-107.

5 Torres, R.C., Self, S., Martinez, M.M.L., 1996. Secondary pyroclastic flows from the June 15, 1991, ignimbrite of Mount Pinatubo. In Newhall, C.G., and Punongbayan (eds.) Fire and Mud: Eruption and Lahars of Mount Pinatubo, Philippines. Quezon City, Philippines, Philippine Institute of Volcanology and Seismology, pp. 665-678.

Voight, B., Komorowski, J.-C., Norton, G.E., Belousov, A.B., Belousova, M., Boudon, G., Francis, P.W., Franz, W., Heinrich,

10 P., Sparks, R.J.S., Young, S.R., 2002. The 26 December (Boxing Day) 1997 sector collapse and debris avalanche at Soufriere Hills Volcano, Montserrat. In Druitt, T. H. \& Kokelaar, B. P. (eds) 2002. The Eruption of Soufriere Hills Volcano, Montserrat, from 1995 to 1999. Geological Society, London, Memoirs, 21, 191-209. 0435-4052/02/\$15.

VONA/KVERT Weekly Release. KVERT, Institute of Volcanology and Seismology FEB RAS. URL:

15 http://www.kscnet.ru/ivs/kvert/van/index.php?type=3.

Widiwijayanti, C., Voight, B., Hidayat, D., Schilling, S.P., 2009. Objective rapid delineation of areas at risk from block-andash pyroclastic flows and surges. Bulletin of Volcanology, 71:687-703. The Geological Society of London, Memoirs, 21: 231262.

20

Wright, H., Pallister, J., McCausland, W., Griswold, J., Andreastuti, S., Budianto, A., Primulyana, S., Gunawan, H., VDAP team, and CVGHM team, In Press. Construction of probabilistic event trees for eruption forecasting at Sinabung volcano, Indonesia 2013-14, Journal of Volcanology and Geothermal Research. https://doi.org/10.1016/j.jvolgeores.2018.02.003

25 Zharinov, N.A., Demyanchuk, Y.V., 2008. The Growth of an Extrusive Dome on Shiveluch Volcano, Kamchatka in 1980 2007: Geodetic Observations and Video Surveys. Journal of Volcanology and Seismology, 2(4): 217-227.

Zharinov, N.A., Demyanchuk, Y.V., 2013. Large Explosive Eruptions of Shiveluch Volcano, Kamchatka Resulting in Partial Destruction of the Extrusive Dome (February 28, 2005 and October 27, 2010). Journal of Volcanology and Seismology, 7(2): $30 \quad 131-144$. 